\title{
Collateral, CENTRAl BANK REPOS, AND SYSTEMIC ARBITRAGE ${ }^{1}$
}

\author{
Falko Fecht Kjell G. Nyborg Jörg Rocholl Jiri Woschitz \\ Frankfurt School University of Zurich, ESMT European University of Zurich \\ of Finance \& Swiss Finance Institute, School of Management \\ Management and CEPR and Technology
}

October 19, 2015

\footnotetext{
${ }^{1}$ We thank seminar participants at the Deutsche Bundesbank (January 2013), Central Bank of Ireland (April 2014), the University of Chicago (March 2015), the University of Wisconsin (March 2015), the ECB Workshop on "Structural changes in money markets: Implications for monetary policy implementation" (September 2013), and the EFA (August 2015) for comments. Fecht: Finance Department, Sonnemannstrasse 9-11, D-60314 Frankfurt am Main, Germany. email: f.fecht@fs.de; Nyborg: Department of Banking and Finance, University of Zurich, Plattenstrasse 14, CH-8032 Zurich, Switzerland. email: kjell.nyborg@bf.uzh.ch; Rocholl: ESMT European School of Management and Technology, Schlossplatz 1, D-10178 Berlin, Germany. email: joerg.rocholl@esmt.org; Woschitz: Department of Banking and Finance, University of Zurich, Plattenstrasse 14, CH-8032 Zurich, Switzerland. email: jiri.woschitz@bf.uzh.ch.
} 


\section{Abstract \\ Collateral, central bank repos, and systemic arbitrage}

Central banks have come under increasing scrutiny over the last few years, in part because of the growth in their balance sheets. Concerns have been raised by central bankers themselves that central banks are increasingly exposed to economic and political risks. It is therefore important to understand more about the processes that shape central bank balance sheets. This paper contributes to this agenda by focusing on the interrelationship between the central bank and banks. In particular, we use a comprehensive dataset of German banks' liquidity uptake in repos with the Eurosystem and the collateral that they have pledged over the period 2006-2010. We document the existence of systemic arbitrage whereby banks funnel credit risk and low quality collateral on to the balance sheet of the central bank. Relatively weaker banks use lower quality collateral to demand disproportionately larger amounts of central bank money (liquidity). This is generic in that it describes the data both before and after the onset of the financial crisis and is facilitated by the Eurosystem's collateral framework. Systemic arbitrage may increase the fragility of the interbank market. The unconventional monetary policies introduced by the ECB in response to the crisis increase the scope for systemic arbitrage.

JEL classification: G12, G21, E42, E51, E52, E58

Keywords: Collateral, repo, systemic arbitrage, central bank, banks, liquidity, money markets, financial health, deposit flows, credit 


\section{Introduction}

Central banks have come under increasing scrutiny over the last few years, in part because of the growth in, and the composition of, their balance sheets. Even central bankers themselves are concerned. For example, Thomas Jordan, President of the Swiss National Bank, has expressed the view that "[a]s a result of the measures implemented during the crisis, central banks took much more risk onto their balance sheets, which could potentially lead to substantial losses" (Jordan, 2012). Klaas Knot, Governor of the Dutch Central Bank and a member of the Governing Council of the European Central Bank (ECB), expands on this: " . . . central banks' balance sheets are becoming more and more exposed to economic risk and political pressure. Eventually, this may result in substantial amount of negative capital in a central bank's balance sheet. This is undesirable, because it could undermine a central bank's credibility..." (Knot, 2013). Nyborg (2015a) argues that central bank collateral policies contribute to these trends, which are a risk to financial stability, and provides evidence from the euro area that central bank balance sheets have expanded into increasingly large fractions of lower quality collateral over time. He also discusses various ways that collateral policies may undermine market discipline and also create distortions in the real economy. ${ }^{1}$ This narrative contrasts with Cochrane (2014), who contends that large central bank balance sheets may help financial stability, but does not consider the factors that affect their composition. It is therefore important to understand more about the processes that shape central banks' balance sheets.

This paper contributes to this agenda by focusing on how the interrelationship between the central bank and banks can ultimately affect the exposure of the central bank. In particular, we use data from the euro area to document what we can think of as systemic arbitrage on the part of banks vis-à-vis the central bank. This involves funneling credit risk and low quality collateral from banks to the central bank and is facilitated by central bank policies. Our findings are generic in the sense that they describe the data both before and after the onset of the financial crisis. Systemic arbitrage may be a contributing factor to financial instability, in part because it lowers the quality of the central bank's balance sheet and in part because it might eventually lead to a less efficient interbank market (discussed below)..$^{2}$

\footnotetext{
${ }^{1}$ Nyborg (2015b) provides an overview of some of the main arguments and findings in Nyborg (2015a).

${ }^{2}$ Bindseil, Nyborg, and Strebulaev (2009) show that interbank markets are allocatively inefficient, even during times of normalcy. Nyborg's (2015a) in-depth study of the Eurosystem's collateral framework advances the idea that it is susceptible to systemic arbitrage.
} 
The interaction between central banks and banks revolves around the need for banks to satisfy reserve requirements and the provisioning of central bank money, or liquidity, by the central bank to banks. Importantly, liquidity is provided to banks either through outright purchases of securities or, as is more common in the euro area, repurchase agreements (repos). The collateral central banks receive and the credit risk they may take on directly affect their balance sheet exposures.

The data we use is supplied by the Deutsche Bundesbank and allows us to study the relation between collateral quality, financial health, and the uptake of liquidity directly in Eurosystem repos at the individual bank level for all German banks over the period 1/2006-10/2010. ${ }^{3}$ We find evidence that banks in worse financial health and with lower quality collateral (more risky and illiquid) borrow more (obtain more central bank money) from the Eurosystem relative to their assets and reserve requirements. Thus, the banking sector passes an overweight of high credit risk and low quality collateral on to the balance sheet of the Eurosystem. Credit risk is not taken into account in Eurosystem repos, neither in the repo rate nor in collateral haircuts. ${ }^{4}$ Thus, our findings are consistent with banks, in aggregate, exploiting this credit risk loophole. Systemic arbitrage is an appropriate terminology for this phenomenon since it means that banks, in aggregate, keep the better collateral and lower credit risk among themselves, without this affecting the interest they pay to the central bank or the amount they borrow.

By way of background, the ECB conducts open market operations predominantly through refinancing operations, which inject central bank money through repos. Banks can also borrow through the ECB's marginal lending facility (discount window). In either case, central bank money is provided against a diverse set of general, or eligible, collateral, ranging from asset backed securities (ABSs) to government bonds. For example, at the end of 2013 the number of unique ISINs in the public list of eligible collateral exceeded 35,000, with unsecured bank bonds and ABSs accounting for approximately $67 \%$ by count and $22 \%$ by value (Nyborg, 2015a). The range of eligible collateral has always been large (Eberl and Weber, 2013, and Nyborg, 2015a). The refinancing operations and the lending facility are open to all banks in the euro area, including branches of foreign banks. This contrasts with the primary dealer system employed, for example, by the Federal Reserve System in the US. The wide range of eligible collateral and the inclusivity of the operations

\footnotetext{
${ }^{3}$ The Eurosystem is the system of central banks in the euro area, comprised of the European Central Bank and the individual national central banks.

${ }^{4}$ In a repo, the credit risk faced by the cash provider relates to the joint event of default by the cash taker and the failure of the collateral pool that backs the repo to cover the loan.
} 
make for an environment in which systemic arbitrage can potentially fester.

The scope for systemic arbitrage was substantially widened as of October 8, 2008, approximately one month after Lehman Brothers' bankruptcy, with the introduction of the full allotment policy. Under this policy, which is still in force, banks receive whatever quantity they ask for in the refinancing operations, subject to having sufficient collateral. Furthermore, all banks pay the same repo rate, regardless of how much they receive. The ECB also relaxed collateral eligibility rules later the same month. Previously, the ECB operated with a liquidity neutral policy, whereby it injects through its operations the liquidity banks need in aggregate to satisfy reserve requirements and other liquidity needs. ${ }^{5}$ The full allotment policy allows banks to bypass the discipline of the (interbank) market for liquidity as well as that of funding markets. Full allotment repo funding has been made available with maturities of up to four years. ${ }^{6}$ This unconventional monetary policy has been accompanied by a substantial increase in the Eurosystem's consolidated balance sheet as well as large excess reserves within the banking sector (see, e.g., Nyborg, 2015a). We find that poorly performing banks have especially large liquidity uptakes under the full allotment policy, suggesting that the policy was especially benefitting weaker banks and regions, as argued by Abbassi, Bräuning, Fecht, and Peydró (2014) and Nyborg (2015a).

While we are the first to document that banks with worse collateral borrow more from the Eurosystem, relative to assets and reserve requirements, our finding that banks in worse financial health also borrow more relates to a similar finding by Fecht, Nyborg, and Rocholl (2011). Our contributions with respect to this second finding are, first, that unlike Fecht et al, we control for collateral quality. Second, we also have a substantially longer and more recent sample period, which includes the changeover to the full allotment policy. Furthermore, while Fecht, Nyborg, and Rocholl only consider main refinancing operations, in the current paper we consider borrowings from all Eurosystem operations and facilities. This matters because, as documented by Nyborg (2015a), since August 2007, the main refinancing operations have played an increasingly smaller, and eventually marginal, role with respect to the quantity of liquidity that is injected through them. We find that banks in worse financial health not only borrow more, but also tend to have worse collateral. This amplifies the credit risk borne by the Eurosystem. It also shows that the credit risk and collateral facets of systemic arbitrage are positively related. These findings hold both before and after the introduction of the full allotment policy.

That banks with worse collateral have larger Eurosystem liquidity uptakes likely re-

\footnotetext{
${ }^{5}$ See Bindseil, Nyborg, and Strebulaev (2009) and Bindseil (2014) for detailed discussions on this policy.
}

${ }^{6}$ Over the sample period, the longest maturity is one year. 
flects the efficient usage of collateral by banks. It is consistent with the idea expressed by Nyborg, Bindseil, and Strebulaev (2002) that Eurosystem haircuts do not equilibrate the opportunity costs associated with using different collateral. In particular, our finding is suggestive of lower quality collateral having lower opportunity costs. There are several reasons as to why this may be the case.

First, lower quality collateral may have low Eurosystem haircuts relative to their levels of risk and illiquidity. This could be by design, to help weaker banks, or could arise from the fact that Eurosystem haircuts are rarely revised and therefore do not reflect market conditions (Nyborg, 2015a).

Second, lower quality collateral also has limited use outside of Eurosystem operations. For example, central counterparty (CCP) repos lock out many securities that are eligible to be used in repos with the Eurosystem. As an example, while the Eurosystem accepts 30,000-40,000 different ISINs (the exact number varies over time), Eurex only accepts 7,000-8,000 of these in their popular Eurex GC Pooling ECB basket contracts. It is especially lower quality collateral that is excluded. ${ }^{7}$

Third, as shown by Ewerhart and Tapking (2008), two-way default risk gives rise to a preference for higher quality collateral in bilateral repos between banks and, by implication, lower quality collateral in repos with the central bank. The logic is as follows: In bilateral repos, lower quality collateral necessitates larger haircuts to protect the cash provider. This has the drawback of leading to larger losses to cash takers in the event that cash providers default, i.e., fail to return the underlying collateral at maturity. Thus, higher quality collateral reduces aggregate default $\operatorname{costs}^{8}$ As a result, using lower quality collateral in repos with the central bank entails lower opportunity costs, since banks benefit by "saving" higher quality collateral for bilateral repos or other transactions they may wish to engage in. Of course, doing this is only possible if the central bank accepts a wide range of collateral, as is the policy in the euro area.

To summarize, in a system where the central bank injects liquidity against a heterogeneous set of collateral, we would expect the central bank to receive the collateral with the lowest opportunity costs to banks. There are institutional as well as theoretical reasons to expect this to be the collateral that is most risky and illiquid. This is what seems to be happening in our data. In addition, weaker banks have relatively large liquidity uptakes

\footnotetext{
${ }^{7}$ See http://www. eurexrepo.com/repo-en/products/gcpooling/(January 20, 2015). Eurex is a central clearing party (CCP). See Nyborg (2015a) for further details on collateral in Eurex contracts versus collateral in Eurosystem operations and for information on eligible collateral over time.

${ }^{8}$ This assumes that default costs are positively related to losses in default.
} 
and also pledge worse collateral. These findings are consistent with the banking sector exploiting the credit risk loophole in the collateral framework.

Systemic arbitrage is a concern not only because it may weaken the central bank's balance sheet, but also because it may reduce the efficiency of the market for liquidity. It weakens market discipline by channeling an overweight of central bank money to weaker banks with worse collateral. It may also foster endogenous heterogeneity across banks with respect to credit risk and collateral quality. Since Eurosystem haircuts are neither adjusted for individual banks' credit risk nor for the correlations between collateral and bank default risk, particularly weak banks have an incentive to pledge collateral that is likely to default when they default themselves. Doing so, they benefit from a risk premium that is paid for a risk that is irrelevant to the bank. In other words, the subsidy from the credit risk loophole is larger when weak banks hold worse collateral and, especially, collateral that is likely to fall in value in states of the world where the bank is likely to default. This also means that there is an underlying incentive within the banking sector to funnel lower quality collateral to weaker banks, thereby making them even weaker. In turn, this undermines the workings of the market for liquidity and makes it more vulnerable to shocks.

This narrative may be relevant for understanding the severe stress that developed around the time of Lehman's default. Several authors have suggested that information asymmetries about credit risk developed (see, e.g., Heider, Hoerova, and Holthausen, 2009), causing problems in the unsecured market (Cassola, Holthausen, and Lo Duca, 2010, and Gabrieli and Georg, 2015). We also know that sovereign bond spreads (over German bonds) started to increase in the second quarter of 2008 and shot up sharply after Lehman's default, suggesting a shortage of riskfree collateral was developing. This reduced the ability of the repo markets to pick up the slack from a stressed unsecured market (apply Ewerhart and Tapking's, 2008, logic). Because it increases the scope for systemic arbitrage, the full allotment policy introduced to alleviate the stress in the markets, may have contributed to worsening them over time instead.

Financial fragmentation along national or regional lines has been a growing concern in the euro area (see, e.g., European Central Bank, 2012, Van Rixtel and Gasperini, 2013, and European Central Bank, 2014). While our detailed bank-level data is limited to German banks, we can nevertheless comment on the increase in market segmentation over the course of the crisis. In particular, we document that German banks use increasingly more German domiciled collateral and less so-called PIIGSC collateral. ${ }^{9}$ We also find that the aggregate

\footnotetext{
${ }^{9}$ PIIGSC is an acronym for Portugal, Ireland, Italy, Greece, Spain, and Cyprus. It is commonly held
} 
Eurosystem liquidity uptake of German banks fall over time, even as total Eurosystem liquidity injections rise. It is documented elsewhere that banks in weaker countries such as Spain and Italy have had especially large liquidity uptakes under the full allotment policy (see, e.g., Nyborg, 2015a). These findings indicate that our evidence on systemic arbitrage from individual German banks represents a microcosm of the broader trends in the euro area.

Systemic arbitrage likely contributed substantially to this fragmentation. Since a domestic government default is likely to be associated with a run on, or default of, weaker banks in the respective country, weak banks in PIIGSC countries have an incentive to invest in the government bonds of their home country. ${ }^{10}$ Thus, ECB collateral policy may contribute to national, and possibly even regional, financial fragmentation in the euro area, strengthening the unfortunate nexus between sovereigns and banks. The full allotment policy and the accompanying increasing Eurosystem balance sheet over the course of the crisis amplify these effects as they increase the scope for taking advantage of the credit risk loophole in haircut policy. This view is further supported by Abbassi, Bräuning, Fecht, and Peydró (2014) who document that the euro area interbank market became also fragmented in the aftermath of the Lehman failure when markets were not concerned with a potential euro area breakup.

Providing banks with such an opportunity for systemic arbitrage implies a subsidization to troubled banks and thus to the financial sector in crisis countries at the expense of the euro area taxpayer. The loss-given-default of banks from crisis countries is larger for the Eurosystem if it holds only collateral that is likely to be worthless in case of a large scale banking default. In turn, this makes it even more important for the ECB to pursue further policies that keep sovereigns and banks from defaulting. The ECB's announcements in September 2014 that it will purchase around EUR 1 trillion worth of asset backed securities, covered bonds, and sovereign bonds (added to the program in January 2015) may be seen in this light (Nyborg, 2015a). The euro area's financial system may thus be increasingly vulnerable because it rests increasingly on the ECB's ability to soak up ever larger quantities of lower quality collateral. In short, consistent with Nyborg (2015a), our analysis suggests that the way banks react to central bank policies may negatively affect central bank exposures and, in Klaas Knot's words, ultimately undermine central bank

that collateral from these countries is of relatively low quality. This is supported by evidence on ratings, as documented by Nyborg (2015a).

${ }^{10}$ See Diamond and Rajan (2011) developing this argument in a theoretical model and Acharya and Steffen (2014) providing evidence for such a behavior of euro area banks. 
credibility. Given the importance attached to central banks these days, a loss of central bank credibility would likely have serious financial, economic, and political consequences.

\section{Overview}

This section provides an overview of key institutional features relating to Eurosystem liquidity injections, banks' collateral pools, collateral values, and haircuts. It also describes the main data in this paper and provides aggregate statistics on German banks' collateral holdings and liquidity uptake over time. Broad euro area statistics on liquidity uptake are also provided. The aggregate statistics shed light on the increasing national fragmentation in the euro area as the crisis unfolded. It also serves as background to the more in-depth panel analysis, using additional bank level data, in Section 3.

\subsection{Central bank liquidity injections and banks' collateral pools}

As touched on in the Introduction, the ECB injects liquidity into the banking sector primarily through its refinancing operations. There are two main types, namely the main refinancing operations (MROs) and the longer term refinancing operations (LTROs). Until September 19, 2007, the MROs were the main source of central bank money in the euro area. After that time, the LTROs have been more important (Nyborg, 2015a). Over the 1/2006-10/2010 sample period of this paper, the maturities of the LTROs range from one month to one year and those for the MROs always equal one week. Until October 7, 2008, the size of these operations were determined according to the ECB's liquidity neutral policy (see the Introduction). Reserve maintenance periods are timed to coincide with every second Governing Council meeting and cover approximately one month. Within a maintenance period, banks need to hold a daily average level of reserves determined by their short term liabilities at the end of the calendar month ending before the start of the previous maintenance period. From October 8, 2008, the MROs and LTROs have been held under the full allotment policy, where banks receive the quantity of liquidity they ask for at the policy rate. The only constraint is that banks need to post sufficient collateral to cover the quantity they receive. ${ }^{11}$

There are two standing facilities. Banks can obtain liquidity from the marginal lending facility (discount window) and place liquidity in excess of reserve requirements at the deposit facility. Before the financial crisis, these rates were always at a spread of 100 basis

\footnotetext{
${ }^{11}$ Further details and statistics can be found, for example, in Bindseil (2014) and Nyborg (2015a).
} 
points (bp) above or below, respectively, the ECB's policy rate. This spread was lowered to $50 \mathrm{bp}$ after the Lehman bankruptcy and raised again to $75 \mathrm{bp}$ in May 2009, where it has remained for the duration of the sample period. Borrowings at the marginal lending facility are overnight, but can be rolled over indefinitely subject to having sufficient collateral.

When a bank obtains liquidity from the Eurosystem through the operations and standing facility described above, the actual repo is with its national central bank. However, the terms, including rates, eligible collateral, and haircuts, are set by the ECB. ${ }^{12}$ In Germany, each bank has an eligible collateral inventory account, or collateral pool, with the Deutsche Bundesbank. Under the pooling system, collateral is not earmarked for particular transactions. ${ }^{13}$ Banks can move eligible collateral in and out of their pool, with the only constraint being that at the end of each day, the total collateral value of a bank's pool needs to be at least equal to a bank's total gross Eurosystem liquidity uptake. ${ }^{14}$ Banks therefore need to pay heed to the ECB's system for determining collateral values.

\subsection{Collateral values and haircut policy}

The collateral value of one unit of collateral $i$ on day $t$ is given by

$$
V_{i t}=\left(1-h_{i t}\right) P_{i t},
$$

where $h_{i t}$ is the Eurosystem haircut and $P_{i t}$ is the market price of the collateral. ${ }^{15} \mathrm{~A}$ bank can borrow a maximum of $V_{i t}$ on day $t$ from the Eurosystem against one unit of collateral $i$.

Eurosystem haircuts are set by the ECB according to a rigid scheme that is rarely modified. Table 1 shows that over the five year sample period of this paper, the Eurosystem's haircut scheme for marketable collateral was updated only once, namely on October 24,

\footnotetext{
${ }^{12}$ By "eligible collateral" we mean collateral that is accepted in the Eurosystem's refinancing operations and marginal lending facility. Until December 31, 2006, the Eurosystem operated with a Tier 1 and Tier 2 eligible collateral system. Whereas Tier 1 collateral were set by the ECB; Tier 2 assets were to some extent under the control of national central banks, though subject to approval by the ECB. European Central Bank (2003) is the last legal document that defines the rules under the two-tier system. With European Central Bank (2005) and European Central Bank (2006) the ECB introduced the single list framework in two steps.

${ }^{13}$ While national central banks in the Eurosystem are generally free to choose whether to pool or earmark collateral, only the Bank of Spain also allows banks to earmark collateral for central bank operations (Bank for International Settlements, 2013).

${ }^{14}$ So usage of the deposit facility does not free up collateral.

${ }^{15}$ In practice, a theoretical price is often used instead of a market price. See Nyborg (2015a) for further discussion and evidence.
} 
2008. Panel A covers the rules that applied up to October 24, 2008, and Panel B covers the period thereafter to the end of the sample period. ${ }^{16}$ As seen, some haircut updates announced on October 23, 2008 came into force two days afterwards and others on February 1, 2009, implying that parts of Panel A applied until that later date.

\section{Insert Table 1 here.}

Table 1 reveals that a collateral's haircut is determined by four main factors. First, it depends on the collateral's type, e.g., central government bond, local government bond, covered bond, unsecured bond, or ABS. Each type is placed in a "liquidity category" by the ECB, with increasingly higher liquidity categories representing types of collateral that are viewed as intrinsically less liquid (and arguably also more risky) and thus receive higher haircuts, ceteris paribus. Among standard marketable collateral, government bonds have the lowest haircuts and ABSs the highest. The haircuts of non-marketable collateral (not shown in Table 1) are higher yet again. ${ }^{17}$

Second, haircuts are increasing in the collateral's residual maturity, ceteris paribus. Third, haircuts depend on the type of coupon; fixed, zero, or floating. Within each liquidity category and residual maturity bucket, the haircuts of fixed coupon collateral are less than or equal to zero coupon collateral. Both residual maturity and coupon type relate to the concept of bond duration. Table 1 shows that haircuts are (weakly) increasing in duration. More generally, haircuts are increasing in risk and illiquidity (as assessed by the ECB). A collateral's Eurosystem haircut is therefore a good candidate for a simple measure of relative collateral quality at a given point in time. This will be explored further in Section 4.

In Panel A, the lowest haircut, 0.5\%, is for collateral of Liquidity Category I (central government and central bank bonds) with residual maturity of less than one year. The largest, $25 \%$, is for inverse floaters with more than 10 years to run.

Ratings are conspicuously absent from Panel A. Until October 2008, the haircuts of eligible collateral were not affected by ratings. However, a rating of $\mathrm{A}-$ (on the S\&P scale)

\footnotetext{
${ }^{16}$ For part of the period covered by Panel A, the ECB operated with a two-tier system for eligible collateral (see footnote 12). This was replaced with a harmonized "single list" of eligible collateral from January 1, 2007. Under this system, collateral is divided into marketable and non-marketable collateral. Panel B: At the time they were introduced, many of adjustments to eligibility criteria and haircuts in Panel B were labeled as being temporary. Nevertheless, most of these modifications are still in place today, though haircuts have in many cases changed further. Nyborg (2015a) provides a comprehensive overview of the development of these and other issues relating to the Eurosystem's collateral framework. Our Table 1 corresponds to the marketable collateral parts of his Tables 6 and 7 .

${ }^{17} \mathrm{~A}$ comprehensive schedule of haircuts is provided in Nyborg (2015a).
} 
or higher was required for collateral eligibility.

The main change introduced in Panel $\mathrm{B}$ is that the minimum ratings requirement is lowered to $\mathrm{BBB}-$. A rating in the $\mathrm{BBB}-$ to $\mathrm{BBB}+$ range adds $5 \%$ to the baseline haircut of paper rated $\mathrm{A}$ - or higher. Panel $\mathrm{B}$ also sees the introduction of a fifth liquidity category. ${ }^{18}$ The general point remains that illiquidity and risk increase Eurosystem haircuts and thereby also decrease collateral values.

\subsection{Data on collateral pools and liquidity uptake}

Our main data consists of detailed information on individual German banks' collateral pools and their net Eurosystem liquidity uptake, or credit. The latter is defined as the total amount of borrowings a bank has outstanding on a given day from the Eurosystem, with these borrowings coming from three possible sources, namely (i) refinancing operations, (ii) the marginal lending facility, and (iii) emergency liquidity assistance, if any. The data has been made available by the Deutsche Bundesbank for the purpose of this research project and includes all banks in their system.

The collateral data consists of various collateral characteristics (to be described below) of individual banks' collateral pools on 667 irregularly spaced days over the period January 18, 2006 to December 31, 2010. The sample frequency increases towards the end of the sample, when collateral and liquidity came to be viewed as more relevant for financial stability. There is at least one sample day in each of the 60 reserve maintenance periods covered by the sample period. Unique bank codes allow us to follow individual banks over time and merge the collateral data with other bank characteristic data (to be discussed in Section 3). Banks' liquidity uptake is part of the collateral data file as are their reserve holdings with the central bank.

The data comprises 1,588 banks that have collateral in their pool on at least one of the 667 sample days, for a total of 813,576 bank-day observations. For each bank-day, we have market and collateral values broken down by the collateral's type and country of origin. ${ }^{19}$ In total we observe 4,323,775 bank, day, country of origin, and type of collateral combinations.

The collateral types relate to the liquidity categories in Table 1. In particular, the data

\footnotetext{
${ }^{18}$ Unsecured bank bonds (labeled credit institution debt instruments) is separated out from traditional pfandbriefen (covered bonds).

${ }^{19}$ The country of origin is the place of establishment of a collateral's issuer. This can either be a European Economic Area (EEA) or a Group-of-Ten (G-10) country.
} 
breaks collateral into: debt instruments issued by central governments and central banks, local and regional governments, agencies and supranational institutions, non-financial corporations, and financial corporations. The latter is further partitioned into jumbo covered bank bonds, traditional covered bank bonds, unsecured credit institution instruments, and other financial corporation debt instruments. The last two categories are further broken down into asset-backed securities and non-marketable collateral. ${ }^{20}$

For each bank-day, we have the quantity weighted averages of the underlying collateral for the following variables: haircut, liquidity category, duration, default probability according to the Bundesbank's own model, and the Herfindahl index (HHI) based on either collateral type or issuer group. The weighting is by collateral value.

Finally, banks are labeled by the Bundesbank as belonging to one of the following sectors, or bank types: Savings banks and their central banks, the Landesbanken; cooperatives and cooperative central banks; private banks ("regular" banks); branches of foreign banks; private loan banks; special purpose banks, and Bausparkassen (building societies). We refer the reader to Fecht, Nyborg, and Rocholl (2011) or Hackethal (2004) for a discussion of the roles different bank types play in the overall German banking system. The main types can be said to be savings banks, cooperatives, and the "regular" private banks.

\subsection{Aggregate collateral pool values and liquidity uptake: Time patterns}

For the purposes of this section, we prune the raw data of 813,576 bank-day observations as follows: First, we exclude 7,029 bank-days with missing country of collateral origin data. Second, we drop 2,544 bank-days with recorded negative reserve holdings or haircuts. Third, we also drop 5,028 bank-days without official bank type information or that relate to a change of bank type. In particular, we drop a bank from any of the five sub-periods we study (defined below) if it has changed its type within that period. The final sample comprises 798,975 bank-days (98.2\% of the initial sample). For each sample day, we work with the aggregate collateral pool and liquidity uptake over all banks. To gauge the liquidity uptake of German banks as compared to that of the rest of the euro area, we also have downloaded weekly data from the ECB's Statistical Data Warehouse on the aggregate

\footnotetext{
${ }^{20}$ Non-marketable collateral is either fixed-term deposits from eligible counterparties, credit claims (bank loans) or non-marketable retail mortgage-backed debt instruments. However, our data does not split up the non-marketables into these sub-categories.
} 
outstanding credit to euro area banks. ${ }^{21}$

Besides aggregate collateral values and liquidity uptake, we also report on portfolio weights in the aggregate collateral pool and on a set of variables labeled "excess collateral." We calculate portfolio weights for the following seven subsets of the collateral pool: (i) Government, central bank, agency, or supranational institution bonds; (ii) Covered bonds; (iii) Corporate bonds; (iv) Uncovered bonds, ABSs, and non-marketables ("Uncovered etc"); (v) German origin; (vi) PIIGSC origin; (vii) Own-use, meaning collateral issued by an entity with which the bank that holds it in its pool has close links, as defined in the official, legal documentation. ${ }^{22}$

The excess collateral variables on day $t$ are defined as

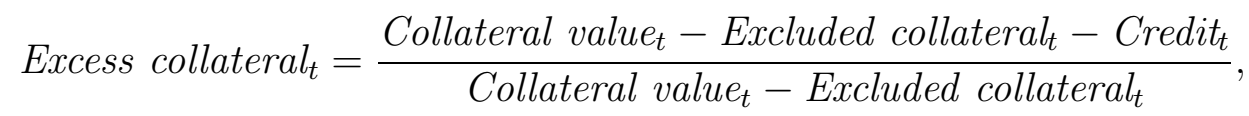

where Excluded collateral $l_{t}$ is the collateral value of an excluded collateral subset, if any. A large excess collateral without exclusions is indicative of low collateral opportunity costs, especially for the collateral types with large portfolio weights. Excess collateral also gauges to what extent German banks may be collateral constrained. By excluding certain subsets of what we may think of as lower quality collateral, the excess collateral variables tell us what the excess collateral value would be if the collateral of the excluded subset were written down to zero. We report on overall excess collateral (no subset excluded) and on values when one of the following three subsets are excluded: (i) Collateral of non-German origin; (ii) Uncovered, ABS, and non-marketables; (iii) the union of "Uncovered etc" and PIIGSC. Excess collateral given these exclusions is informative with respect to the strength of the aggregate collateral pool and, by implication, German banks.

To get a sense of how these variables have evolved over time, we report on their average values over the following five sub-periods: (1) "2006." January 18, 2006 to January 16, 2007. (2) "Pre-Crisis." January 17, 2007 to August 7, 2007. (3) "Crisis-to-Lehman." August 8, 2007 to September 9, 2008. Lehman Brothers filed for bankruptcy on September 15, 2007. 23 (4) "Post-Lehman." September 16, 2008 to January 19, 2010. (5) “2010." January 20, 2010 to December 31, 2010. Thus, for periods (1)-(3) and the first month of

\footnotetext{
${ }^{21}$ Downloaded from http://sdw.ecb.europa.eu/browse.do?node=bbn129 (January 20, 2015).

${ }^{22}$ Entities A and B are said to have close links (i) if one of them directly or indirectly owns or controls $20 \%$ or more of the capital or voting rights of the other, or (ii) a third party directly or indirectly owns or controls the majority of the capital or voting rights of both A and B (European Parliament and Council, 2000). See also European Central Bank (2005) footnote 50 and European Central Bank (2010).

${ }^{23}$ The start date (end date) for each sub-period is chosen to correspond to the beginning (end) of a maintenance period, except (i) sub-period (4), where we begin the period the day after Lehman's bankruptcy
} 
period (4), the liquidity neutral policy applies and haircuts are set according to Table 1, Panel A. For most of period (4) and the whole of period (5), the full allotment policy applies, as do haircuts from Table 1, Panel B.

Because the sampling frequency carried out by the Deutsche Bundesbank varies over time, we use the following procedure to average within each sub-period. First, we take the equally weighted average across all sample days within the same maintenance period. We do the same for the weekly aggregate Eurosystem credit figures. Second, we take the equally weighted average across all maintenance periods in each of the five sub-periods. We also do this for the whole sample period.

Table 2 shows the patterns of the average values for our variables for the full sample period and the five sub periods. Panel A shows that from 2006 to 2010, German registered banks reduce the aggregate liquidity uptake from EUR 233.0 to 149.6 billion, or by $35.8 \%$. Over the same time period, Eurosystem liquidity injections increase from EUR 424.1 to 653.1 billion. German banks' share of total Eurosystem credit thus drops from $54.94 \%$ in 2006 to $22.91 \%$ in 2010. Most of this decrease occurs in 2010, coinciding with the maturity of the first ever one-year LTRO (July 1, 2010), where EUR 440 billion fell due. The dramatic decrease is testament to the increasingly fragmented market for liquidity in the euro area. Under the view that German banks suffered less as the crisis progressed than banks in other parts of the euro area, this constitutes a first piece of evidence that worse banks have a relatively larger uptake of liquidity from the central bank.

\section{Insert Table 2 here.}

Panel A also shows that German banks' aggregate collateral pool value vastly exceeds their liquidity uptake. Even in 2006, the aggregate coverage ratio (collateral value to credit) is more than two to one. It has grown over time, reaching 4.47 as an average in 2010. This indicates that there has always been little use for much of the collateral held by German banks outside of Eurosystem operations. It supports the view that the ECB's wide range of eligible collateral is designed to support weaker countries and points to a potential problem at the core of the single currency, as extensively discussed by Nyborg (2015a).

The aggregate portfolio weights in Panel B show that collateral quality decreases over time from 2006 to Lehman's bankruptcy, but recovers thereafter. For example, from 2006

rather than the first day of the relevant maintenance period, September 10, 2008. One weekly Eurosystem aggregate credit data point drops out (but this has no noteworthy effect on the statistics we calculate). The Bundesbank data has no sample days in the period September 10-15, 2008. (ii) The end date in sub-period (5) corresponds to the end of our sample, rather than the end of a maintenance period. 
to "Lehman," there is a shift of approximately 10 percentage points (pp) from government and covered bonds to "Uncovered etc" collateral. The trend continues but at a much weaker pace into the post Lehman period, but then reverses somewhat, especially for government bonds, whose weight increases by around 6 pp from "Lehman" to 2010. There are also large shifts taking place with respect to the origin of the collateral used by German banks in repos with the Eurosystem. From 2006 to "Lehman," German domiciled collateral decreases by around $10 \mathrm{pp}$, while PIIGSC collateral increases by 6 pp. After Lehman's bankruptcy and the introduction of full allotment, there is a sharp reversal. German domiciled collateral increases by around 18 pp to $63.04 \%$, while PIIGSC collateral falls around 14 bp to $13.54 \%$. This provides further evidence of financial fragmentation in the euro area.

These numbers also show that German banks reduce risks in the aftermath of Lehman's bankruptcy and the introduction of the full allotment policy. This is at odds with claims that there has been widespread increase in risk taking behavior across the euro area over this time period (e.g., Drechsler, Drechsel, Marquez-Ibanez, and Schnabl, 2013). ${ }^{24}$

Panel C shows that, overall, collateral in excess of credit increases from $52.90 \%$ in 2006 to $77.95 \%$ in 2010 . Thus, German banks are not collateral constrained. However, excluding all "Uncovered etc" and "PIIGSC" collateral, the excess collateral is actually negative from

\footnotetext{
${ }^{24}$ Drechsler et al (2013) use a euro area wide sample of only 292 banks and find that those with worse ratings in 2007 experience a relatively large decrease in the average rating of their collateral pool holdings as well as PIIGS collateral after June 2010 while at the same time also seeing a relative increase in their liquidity uptakes. Rather than reflecting increased risk taking, this is the result of the north-south divide in the euro area, with private liquidity fleeing the PIIGS(C) countries as deficits, indebtedness, and yield spreads increased dramatically. Ratings of $\operatorname{PIGS}(\mathrm{C})$ countries and their banks also fell, reflecting these realities. The lost private liquidity from this market fragmentation, was necessarily replaced by increased public liquidity from Eurosystem operations, lest the banking sectors of the PIIGS(C) countries should collapse. The sharp increase in the graphs provided by Drechsler et al in July 2010 coincides with the maturity of the first one-year LTRO, where, as noted above, EUR 440 billion fell due. This was an emergency measure that preceded the more well known three year LTROs, but was equally large. The finding in Drechsler et al is driven by non-PIIGS(C) countries not refinancing these loans in the operations following on from the maturing one-year LTRO. It was not possible to repay this early. Their liquidity uptake graphs show little by way of any effect after the one-year LTRO matured. Thus, what happened was a latent decrease by the better banks. Around the same time, non-PIIGS(C) banks started unloading PIIGS(C) collateral, thus reducing their risks, as seen in our German data. These effects from fragmentation is what Drechsler et al are picking up. Drechsler et al neglect to discuss the falling due of the one-year LTRO in the context of their results and fail to understand that the full allotment policy was put in place to support weak banks and sovereigns. Drechsler et al also erroneously claim that differences in the behavior of strong and weak banks only emerged after the sovereign debt crisis. We show below that this is not the case, they always existed.
} 
2006 until the post-Lehman period. In the pre-crisis period, it is a whopping - 28.03\%, suggesting that German banks may have been under some pressure up to Lehman's bankruptcy. This subsequently reversed. In 2010, the excess collateral excluding "Uncovered etc" and "PIIGSC" collateral is at its highest ever level at 49.95\%. This supports our conclusion from Panel B that German banks reduced risks as the crisis progressed.

Overall, the aggregate statistics indicate dramatic shifts in Eurosystem liquidity uptake and collateral holdings across banks in the euro area as the crisis unfolded. They show financial fragmentation along national lines and support the view that the full allotment policy was introduced to support weak banks. They also support the view that relatively stronger banks obtain relatively less credit from the Eurosystem. Next, we exploit the panel structure of our data to study this latter point in more detail, under both the liquidity neutral and full allotment polices.

\section{Panel data, variables, and descriptive statistics}

In this section and in the remainder of the paper, we utilize the panel structure of our data. We add data on financial health and deposit flows to the collateral and liquidity uptake data. All data is supplied by the Deutsche Bundesbank.

\subsection{Data}

We clean the main data on collateral and liquidity uptake before combining it with the new data (described below). This is done slightly differently than for the aggregate analysis, since now we are concerned with having complete data for each individual bank. Starting with the 813,576 bank-day observations in the raw data described in Subsection 2.3, we first remove 646 bank-day observations due to missing or zero collateral values. We also drop: 8,129 bank-day observations with negative or missing haircuts $;{ }^{25}$ 5,954 additional bankdays with incomplete collateral data; 173 outliers (from five banks) where liquidity uptake exceeds daily reserve requirement by a multiple of more than 1,000; 2,455 observations with negative reserve holdings; 2,684 observations for which either bank type information is missing or the bank's official type changes within the sample period. We also exclude the two consecutive maintenance periods that include Lehman Brothers' bankruptcy and the start of the ECB's full allotment policy. This covers the period September 10-November

\footnotetext{
${ }^{25}$ These observations include the 7,029 bank-day observations without information on the country of origin in Section 2.4 .
} 
11, 2008 and reduces the sample by 8,424 bank-day observations. Finally, we lose 74,049 bank-days because the reserve data ends in October 2010 and is also only available for banks that were required to hold reserves as of that month.

The final collateral and liquidity uptake data consists of 711,062 bank-day observations (87.4\% of the raw data). Along the same lines as for the aggregate analysis, for each bank, we average variables (described below) across sample days within each maintenance period. This leaves us with 55,334 bank-maintenance period observations.

We combine the bank-maintenance period sample with monthly balance sheet and yearly income statement data for all German registered banks. From the former we get a bank's book value of total assets at the end of each calendar month, which we use to capture bank size, book value of equity, and end-of-month deposits from banks and non-banks (that we use to measure deposit flows). From the income statements, we obtain write-offs and provisions as well as return on assets (ROA).

We merge the three datasets by, for each bank-maintenance period, using the monthly balance sheet statistics (yearly income statement statistics) that apply at the end of the month (year) immediately preceding the start of the maintenance period. Deposit data are handled specially and described in the next subsection. In doing this, we drop 1,501 bankmaintenance period observations without information on total assets, book value of equity, write-offs and provisions, ROA, or deposits. The final data on which we will carry out the panel analysis covers 56 maintenance periods and consists of 53,833 bank-maintenance periods involving 1,360 banks.

No banks in the Bausparkassen category survived the data filtering process. As noted by Fecht, Nyborg, and Rocholl (2011), these institutions have reserve requirements that are almost zero and therefore end up as extreme outliers in measures involving reserves. However, the final sample includes banks from all the other eight bank types.

\subsection{Variables}

The variables are divided into five categories; credit (liquidity uptake), collateral quality, financial health, deposit flow, and (collateral) concentration. All variables are per bank per maintenance period, as described above.

Credit is equally weighted across sample days within each maintenance period and normalized by either total assets or daily average required reserves and expressed as a percentage of these. Credit normalized by total assets shows how much of a bank's balance sheet is financed by the ECB. Credit normalized by daily reserve requirements gives a 
factor of how many times a bank takes more credit from the Eurosystem than it needs to cover average daily reserve requirements (for example, the maximum is 446 in the pre-crisis period). In most of our regressions in Section 4, the variable on the left hand side is a bank's normalized credit.

The collateral variables are quantity weighted by collateral value across a bank's collateral pool for each sample day and then averaged across each maintenance period. Collateral quality variables are haircut, duration, probability of default (from the Bundesbank's proprietary model), liquidity category, and own-use. The latter is the collateral value of own-use collateral divided by total collateral value in a bank's pool. The concentration of a bank's collateral pool is measured by the Herfindahl index (HHI) based on either collateral class or issuer group.

We use the same three financial health variables as Fecht, Nyborg, and Rocholl (2011), namely (i) the equity ratio, defined as the book value of equity divided by total assets (balance sheet, monthly), (ii) write-offs and provisions (income statement, yearly) and (iii) ROA (income statement, yearly).

Deposit flows are based on monthly deposit data from banks' balance sheets and divided into bank and non-bank flows, both normalized by either assets or reserve requirements. Thus, there are four deposit flow variables in total. We are interested in deposit flows as a control to liquidity uptake and therefore wish to use it for the maintenance period that is contemporaneous to liquidity uptake. However, maintenance periods do not correspond to calendar months. We therefore proceed as follows, using the bank deposit flow normalized by assets as an example.

First, for each bank $i$ and month $t$, define $\Delta$ Deposits $_{i, t}=$ Deposits $_{i, t}-$ Deposits $_{i, t-1}$, where Deposit refers to bank deposits. Second, for maintenance period $p$, define

$$
\Delta \text { Deposits }_{i, p}=\frac{d_{t-1} \times \Delta \text { Deposits }_{i, t-1}+d_{t} \times \Delta \text { Deposits }_{i, t}}{d_{t-1}+d_{t}},
$$

where $d_{s}$ is the number of days in month $s$ that are in maintenance period $p$. This gives an estimate of the average daily bank deposit flow in maintenance period $p$. Finally, for bank $i$ in maintenance period $p$ we define the normalized deposit flow as

$$
\text { Normalized deposit flow }_{i, p}=\frac{\Delta \text { Deposits }_{i, p}}{\text { Total assets }_{i, p}}
$$

where Total assets $s_{, p}$ is the total assets the last month before the start of maintenance period $p$. When we normalize by reserve requirements, we use the daily average reserve requirement for maintenance period $p$. Normalized non-bank deposit flows are defined analogously. 


\subsection{Descriptive statistics}

We report descriptive statistics over three sub-periods as well as the total sample period. In the panel analysis, we use longer sub-periods than under the aggregate analysis in Subsection 2.4 in order to increase the power of our tests. The sub-periods are: (1) "Precrisis." January 18, 2006 to August 7, 2007. (2) "Early Crisis." August 8, 2007 to September 9, 2008. (3) "Full Allotment." November 12, 2008 to November 9, 2010. The start (end) date of each sub-period always coincides with the start (end) of a maintenance period. The number of maintenance periods in each period are 19, 13, and 24, respectively.

Table 3 reports the descriptive statistics of our key variables for the three sub-periods "Pre-crisis," "Early Crisis," and "Full Allotment" as well as for the total sample (January 18, 2006 to November 9, 2010 excluding September 10 to November 11, 2008). For each sub-period, we first take an equally weighted average across bank-maintenance periods for each bank, leaving us with a population of bank-subperiod observations. ${ }^{26}$ The descriptive statistics thus capture cross-sectional features of the data within each sub-period. However, when we run regressions in the next section, we fully use the panel structure of the data. Table 3 reports on normalized credit, collateral quality, bank financial health, normalized deposit flow, and concentration measures for the three sub-periods, shown in Panel A, $\mathrm{B}$, and $\mathrm{C}$, respectively, and the full sample period, shown in Panel D. For reasons of data confidentiality, we are not allowed to report statistics that are taken from a single observation. Therefore, instead of minimums and maximums, we average the three smallest and three largest observations (for the relevant variable), which we refer to as Min3 and Max3, respectively. For the median we average three (four) observations around the median if the number of observations is odd (even). This variable is referred to as Median34. All references to a minimum, maximum, or median, below, refer to the Min3, Max3, or Median34 statistics, respectively.

\section{Insert Table 3 here.}

The descriptive statistics on liquidity uptake show that normalized credit is truncated at zero. Many banks do not ask for Eurosystem credit even though they have collateral in their pools. Overall, both the average and the median bank's credit normalized by total assets increase from the pre-crisis period to the full allotment period. Interestingly, the

\footnotetext{
${ }^{26}$ Note that our basic collateral and liquidity uptake data are provided for all banks with collateral in their respective pools. The averaging for each bank here is therefore across maintenance periods on which a bank has collateral in its pool (on at least one of the sample days).
} 
median approached the mean indicating that more banks demanded significant amounts of credit from the ECB towards the end of our sample. Our analysis shows that credit flow measures are well behaved when we normalize by total assets. We therefore focus on credit normalized by total assets in the text, as we will do in the panel regressions below. ${ }^{27}$

As regards collateral quality, with the exception of the probability of default all quality measures have increasing means from the pre-crisis to the full allotment period, indicating a deterioration of collateral quality over time. Overall the dispersion of those indicators across banks also tends to increase over time providing first suggestive evidence of a segmentation within the German banking sector, i.e., some banks' collateral pools worsening relative to others. As seen in Table 1, haircuts changed in October 2008 and liquidity categories in February 2009. Some of the changes from the early crisis to full allotment sub-periods reflect this. This will be controlled for in the panel regressions by using maintenance period fixed effects.

The descriptive statistics on our financial health indicators provide a less consistent picture. The equity ratio remains on average almost constant over the sub-periods with a slightly increasing median. While the mean write-offs and provisions decreases over the three sub-periods, ROAs decreased from $0.18 \%$ in the pre-crisis period to $0.05 \%$ in the full allotment period.

The deposit flows from banks and from non-banks increase from the pre-crisis to the full allotment period, whereby the mean for both is higher for the early crisis then in the full allotment period. Also the dispersion of the two measures across banks seems to increase over time suggesting that banks became more dissimilar in their deposit in- or outflows. This is consistent with the idea that markets, even within Germany, became more segmented. It may also reflect that the number of banks in the sample changes over time.

Each panel also reports on the number of banks in the dataset, broken down by bank type. The introduction of the full allotment sees a huge growth in the number of sample banks, from 833 in the early crisis period to 1,335 under full allotment. Since the dataset is comprised of all banks with collateral in their respective eligible collateral accounts with the Bundesbank, this shows a dramatic change in banks' behavior after full allotment was

\footnotetext{
${ }^{27}$ Normalizing by daily reserve requirements is highly dependent on end-of-calender month short-term liabilities held from outside the euro area two months before the beginning of the relevant maintenance period. These liabilities seem to fluctuate much more than total assets for our sample period. The same holds for the deposit flow measures that we are going to analyze below. See, for example, Fecht, Nyborg, Rocholl (2011) for a more detailed discussion on reserve requirements.
} 
introduced. The largest increase is among cooperatives, where the number goes from 363 to 774 . This suggests that cooperatives were particularly hit by the crisis.

\section{Insert Table 4 here.}

The descriptive statistics in Table 4 complement the results from Table 3 by providing averages for five different size groups for the three sub-periods (Panels A, B, and C) and the full sample period (Panel D). The five size groups comprise the four quartiles of the size distribution, in which the fourth quartile, which represents the largest banks, is further separated between banks in the 75th to 99th percentile group and the largest percentile of banks, representing 14 banks. $^{28}$ The evidence in Panel A and Panel B of Table 4 suggests that this largest percentile of banks asks for more credit relative to their total assets in the pre-crisis and the early-crisis period (3.17\% and $2.57 \%$, respectively) compared to the smallest quartile of banks ( $0.59 \%$ and $0.48 \%$, respectively). As shown in Panel C of Table 4 , this relation reverses in the full allotment period. Now, the largest percentile of banks asks for $1.61 \%$ credit relative to their total assets and the smallest quartile asks for $2.42 \%$ credit relative to their assets. Again, as shown in Table 3, in the full allotment period, many smaller banks put collateral in the pool (1,335 in total) that did not put collateral in the pool in the pre-crisis or the early-crisis period (879 and 833 banks, respectively).

In the next section we fully use the panel data structure on a bank-maintenance period level to study correlations between these variables.

\section{Panel regressions}

This section studies the relation between banks' liquidity uptake, collateral quality, financial health, and deposit flows at the individual bank level. For this purpose, we examine in particular Eurosystem haircuts as an indicator of collateral quality.

\subsection{Collateral quality}

Tables 5 and 6 provide the results for the panel regressions. The dependent variable is the average haircut that each bank experiences on its collateral in each maintenance period. This variable thus represents a measure of the quality of the collateral that a bank possesses

\footnotetext{
${ }^{28}$ We build bank size groups according to the average size over the full sample period to make sure that banks do not switch size groups over time. Therefore, the table shows that mainly smaller banks joined the group of banks that put collateral in the pool from pre-crisis and early crisis to the full allotment period.
} 
in each of these maintenance periods. We regress this dependent variable on a number of explanatory variables, in particular the financial health of the bank in this maintenance period, which is measured by its equity ratio, its write-offs and provisions as a percentage of total assets, and its return on assets (ROA). These regressions are run for the full sample period of 56 maintenance periods as well as for three sub-periods. As described before, these sub-periods comprise the pre-crisis period (January 1, 2006 to August 7, 2007) with 19 maintenance periods, the early-crisis period (August 8, 2007 to September 9, 2008) with 13 maintenance periods, and the full allotment period (November 12, 2008 to November 9, 2010) with 24 maintenance periods. The total period thus does not include the two consecutive maintenance periods in which Lehman Brothers went into bankruptcy and the full allotment policy was introduced. These regressions are run in a plain panel setup (Table 5) and with a Heckman correction (Table 6). Both tables include fixed effects for banking groups (shown) and maintenance periods (not shown). The first four columns in each table report results when standard errors are Huber-White (heteroskedasticity) adjusted. The second four columns show results when standard errors are clustered on the individual bank level.

\section{Insert Table 5 here.}

The evidence in Table 5 suggests that healthier banks have better collateral, while banks that are worse off have worse collateral in their pool. In particular, the panel regressions show that banks with a lower equity ratio have significantly higher haircuts in all sub-periods. Clustered standard errors weaken the statistical significance of the results. However, the negative coefficient in the early-crisis period remains statistically significant at the $10 \%$ level. In terms of economic significance, in the early-crisis period, if the equity ratio decreases by 1 percentage point, the haircut increases by 0.028 percentage points. Likewise, the coefficients on ROA are negative in all periods and statistically significant at the $1 \%$ level in the pre-crisis and early-crisis periods, when using Huber-White standard errors. Banks with relatively higher write-offs and provisions exhibit higher haircuts in the early-crisis and in the full allotment period. Clustering on the banks weakens the statistical significance in the full allotment period. In the pre-crisis period, however, the coefficient on write-offs and provisions is significantly negative even in the clustered standard errors scenario ( $5 \%$ level). We will come back to this odd result when re-running the panel regressions in Table 6 using a Heckman selection correction.

The estimation methodology in Table 5 examines the haircuts of all banks' collateral pools, regardless of whether the bank actually took liquidity from the Eurosystem. This 
may be important because, in the data, there are many bank-maintenance period observations with zero credit. In Table 6 we take account of this using a Heckman selection model. This model combines a selection mechanism for having a positive liquidity uptake with a panel regression model of haircuts on the same variables as in Table 5.

Indexing banks by $i$ and maintenance periods by $j$, the selection equation is

$$
z_{i j}^{*}=\gamma^{\prime} w_{i j}+\mu_{i j}
$$

The regression model is

$$
y_{i j}=\beta^{\prime} x_{i j}+\epsilon_{i j}
$$

where $\left(\mu_{i j}, \epsilon_{i j}\right)$ are assumed to be bivariate normal $\left[0,0,1, \sigma_{\epsilon}, \rho\right]$.

$z_{i j}^{*}$ is not observed; the variable is observed as $z_{i j}=1$ if $z_{i j}^{*}>0$ and 0 otherwise with probabilities $\operatorname{Prob}\left(z_{i j}=1\right)=\Phi\left(\gamma^{\prime} w_{i j}\right)$ and $\operatorname{Prob}\left(z_{i j}=0\right)=1-\Phi\left(\gamma^{\prime} w_{i j}\right) . z_{i}=1$ indicates that the bank has positive liquidity uptake (takes credit) and $\Phi$ is the standardized normal cumulative distribution function.

In the selected sample,

$$
E\left[y_{i j} \mid z_{i j}=1\right]=\beta^{\prime} x_{i j}+\rho \sigma_{\epsilon} \lambda\left(\gamma^{\prime} w_{i j}\right),
$$

where $\lambda$ is the inverse Mills ratio.

The model is estimated by maximum likelihood, see Greene (2000), which provides consistent, asymptotically efficient parameter estimates. We consider standard errors that are adjusted for heteroskedasticity by the Huber-White estimate of variance and standard errors calculated from using a variance structure with clustering at the individual bank level as in Table 5.

The set of explanatory variables, $x$, in the main regression equation are the same as in the plain panel regressions in Table 5 (including the fixed effects). The selection equation includes one additional variable, namely Positive liquidity uptake ${ }_{j-1} \cdot{ }^{29}$ This is 1 if bank $i$ has positive credit from the Eurosystem in maintenance period $j-1$ and zero otherwise.

\section{Insert Table 6 here.}

The results are in Table 6 and are along the same lines as in Table 5. A notable difference is that the coefficient on write-offs and provisions in the pre-crisis period changes sign, from negative and significant (1\% level with Huber-White, $5 \%$ level with clustering) in Table 5 to

\footnotetext{
${ }^{29}$ We have also used the two deposit flow variables in the selection equation, without this making a noteworthy qualitative difference to the results.
} 
positive and significant (1\% level with Huber-White, $10 \%$ level with clustering) in Table 6 . This provides further support for the view that banks in worse financial health use worse collateral when obtaining central bank money, especially in the pre-crisis period. The result on the equity ratio tells the same story; the coefficient is negative and statistically significant (5\% level) with clustering in the pre-crisis period. Clustering leaves us with coefficients on the financial health variables that are not statistically significant at conventional levels in the two crisis sub-periods. This could be the result of the model being misspecified or a consequence of not having sufficient variation in the explanatory variables; write-offs and provisions and ROA are measured only at yearly frequencies, and we have used them lagged one year. We will explore this further in subsequent versions of this paper. Note, however, that the p-values continue to be fairly low in some cases. For example, for writeoffs and provisions in the full allotment period, the p-value is $12.2 \%$ (and the coefficient is positive). This is a fairly strong result given the yearly measurement frequency of the variable. Overall, the results in Tables 5 and 6 indicate that weaker banks have worse collateral.

Table 7 provides further verification that haircuts are indeed a good measure for the quality of the collateral. Panel A of Table 7 exhibits the correlation between the "collateral quality ingredients," duration, default probability, and liquidity category. These correlations are again calculated for the three sub-periods as well as for the full sample period, which excludes as before the two maintenance periods surrounding the bankruptcy of Lehman Brothers.

\section{Insert Table 7 here.}

Panel B provides the results for the regressions in which haircut is the dependent variable and the three ingredients are the explanatory variables. All these ingredients are highly statistically significant in explaining the haircuts, as indicated by the adjusted R-squares that range between $23.55 \%$ and $67.27 \%$. In particular, the haircuts for the collateral are higher if it has a longer duration, if it is more likely to default, and if it is less liquid. This holds true in all sub-periods, with one exception, namely the coefficient on the probability of default is negative in the pre-crisis period. This is rather odd, especially because the probability of default is calculated from the Bundesbank's own model. Overall, the results in Table 7, Panel B support the view that haircuts capture collateral quality. 


\subsection{Liquidity uptake}

The previous results show that the quality of the collateral that a bank has increases in the bank's financial health. The next question is how much credit a bank has in a given maintenance period based on the quality of its collateral, its financial health, and its deposit flows. To examine this, we run Tobit regressions, to account for the fact that our left hand side variable, normalized credit (or liquidity uptake), is truncated at zero.

\section{Insert Table 8 here.}

Table 8 provides the results for the Tobit regressions in which the dependent variable is the credit that a bank obtains on average in a given maintenance period. The absolute amount of credit is normalized by a bank's total assets. We run the regressions with maintenance period and bank sector fixed effects and both with Huber-White adjusted standard errors and standard errors clustered on the individual bank level.

The empirical evidence in Table 8 suggests that the financial health of a bank and the quality of its collateral as measured by the haircut have a significant impact on the amount of credit that a bank has in a given maintenance period. Importantly, a higher haircut leads to significantly more credit in a given maintenance period. Controlling for an unobserved bank effect by clustering at the bank level weakens the results, but the main variables are still statistically significant at conventional levels, indicating the strengths of the results, especially given that the financial health variables do not vary much. This result suggests that banks with worse financial health obtain more credit, and they succeed in obtaining this credit by providing worse collateral. These results point to systemic arbitrage by which banks with worse financial health use collateral of worse quality to secure central bank money.

With regards to the effect of financial health, the results on the equity ratio show that firms with relatively more healthy equity positions have lower liquidity uptakes. In the specification with Huber-White standard errors, the coefficients are negative and statisti-

cally significant in every sub-period. In general, the result that banks in weaker financial health have larger liquidity uptake is especially strong under the full allotment period. This can be seen in the specification with bank-level clustered standard errors, which reduces the estimated statistical significance. In this specification, the coefficient on the equity ratio loses statistical significance in the early-crisis period, but remains significant and negative in the pre-crisis and the full allotment period.

To account for the possibility of a nonlinear relation between the equity ratio and 
liquidity uptake, we have also included a square term (of equity ratio). This is positive and statistically significant at least at the $10 \%$ level in all sub-periods and using both types of standard errors. This indicates that the relation between the equity ratio and normalized credit is downward sloping and convex, which makes intuitive sense.

The results on write-offs and provisions also support that systemic arbitrage is especially a concern under the full allotment period. In the clustered standard errors specification, the coefficient on write-offs and provisions is statistically significant at least at the $5 \%$ level across specifications. However, the coefficient changes from negative in the two prefull allotment sub-periods to positive under full allotment. This is also consistent with systemic arbitrage being stronger under the full allotment period. The negative coefficients in the two earlier sub-periods, however, are surprising. This may be a result of relatively weaker banks "hiding" losses before the worst onslaught of the crisis. Such behavior could explain why the results are weaker for the equity ratio in the early-crisis period as well. As the crisis progressed, hiding losses may have become increasingly difficult to do.

Table 8 also uses the two deposit flow variables as controls. These measures are important as they capture the extent of deposit inflows that a bank receives from private markets, which in turn determine its need for more credit from the Eurosystem. Furthermore, banks perceived as being better than others might experience a significant deposit inflow and thus having a relatively lower need for getting liquidity directly from the central bank. In contrast, banks perceived as being worse might be exposed to deposit outflows and are thus in need of central bank money. The results on deposit flow are interesting. An increase in deposit flows from non-banks, is associated with a decrease in Eurosystem credit in both the pre-crisis and early crisis periods. Bank-deposit flows have the opposite effect. Thus, while non-bank deposits appear to be a substitute for Eurosystem credit, bank deposits are complements. The effect of either kind of deposit disappears after the onset of the full allotment policy, showing the strong effect this policy has had on banks' liquidity management.

Table 9 reports on very similar regressions to those in Table 8 and the results are similar as well. What's new in Table 9 is first that we break out the haircut into the haircut composition measures, duration, default probability, and liquidity category (see Table 7). We add as a fourth variable the residual of the OLS regressions of haircut on the three mentioned variables, i.e., the components of the haircut that the three ingredients are not able to explain. ${ }^{30}$ We also include collateral own-use, which measures the fraction of

\footnotetext{
${ }^{30}$ The residuals are from cross-sectional regressions within each maintenance period.
} 
collateral issued by an entity with which the bank that holds the collateral has close links. For this fraction of collateral, the probability of default is - per definition - highly correlated with the default of the bank that holds it in the pool. This is therefore a perfect variable to examine the idea that banks have an incentive to use such highly correlated collateral to take advantage of the credit risk loophole in the Eurosystem's collateral framework. Second, we run these regressions for all eight banking groups in Germany (Table 9, Panel A) as well as for the six banking groups that exclude special purpose banks and private loan banks as a robustness check (Panel B). These two banking groups are not the drivers of our results.

Table 9 reports that the quality of collateral, as measured by its various components, continues to be highly significant in explaining the extent to which a bank obtains Eurosystem credit. For example, the probability of default is statistically significant throughout all the regressions. The variables that capture a bank's financial health are essentially the same as in Table 8, as we would expect.

\section{Insert Table 9 here.}

The results on own-use are mixed. In Panel A, own-use is associated with a statistically significant increase in liquidity uptake in the full allotment period, as we might expect under the systemic arbitrage hypothesis. The result is weaker under the clustered standard error specification. The result also disappears when removing the two very special bank types, special purpose banks and private loan banks in Panel B. In this panel, we also see negative and statistically significant coefficients on own-use in the pre-crisis and early-crisis periods. As seen in Tables 3 and 4, own-use collateral is insignificant for all but the very largest banks. Thus, our finding here points to a pre-full allotment type of behavior among large banks whereby an increase in own-use collateral is associated with less credit. A potential explanation for this is that own-use collateral is associated with securitization activities, with higher own-use capturing a higher level of securitization. If so, the negative coefficient makes sense as more securitization may mean that more assets go off the balance sheet and therefore the need to take Eurosystem credit falls.

\section{Conclusion}

In this paper we have first documented that, on aggregate, German banks reduced their borrowings from the Eurosystem after the Lehman failure and the introduction of the full allotment policy relative to the other euro area banks. While the quality of eligible 
collateral held by German banks with the Eurosystem declined until Lehman's default, from October 2008 onwards German banks have increased their overall collateral holdings relative to their Eurosystem liquidity uptake and improved the average quality of their collateral. German banks on aggregate reduced the share of uncovered bonds, ABS and non-marketable collateral, while they increased the share of bonds issued by non-PIIGSC sovereigns.

Despite these aggregate developments, our panel analysis at the individual bank level provides evidence of systemic arbitrage by German banks both before and after the onset of the financial crisis. That is, weaker banks generally use lower quality collateral to borrow disproportionately more from the Eurosystem than stronger banks. It is noteworthy that this is not unique to the crisis. It points to a fundamental problem in the way money is injected into the banking sector in the euro area.

In Eurosystem repos, solvent banks are obliged to provide additional collateral in case the collateral value of their pledged assets falls short of their outstanding credit with the Eurosystem. Therefore, the Eurosystem's exposure is confined to the risk that a bank fails while at the same time the pledged collateral does not cover the outstanding credit. Systemic arbitrage increases this risk, worsening the Eurosystem's balance sheet and putting taxpayers' money at risk. Moreover, since systemic arbitrage benefits weak banks it undermines market discipline, distorts competition in the banking sector, and might even aggravate tensions in money markets.

Systemic arbitrage could be prevented if the correlation risk - the risk that a bank defaults while its pledged collateral fails to cover the outstanding credits - is correctly reflected in the rates at which a bank obtains credit from the Eurosystem. This is hardly practical under today's system, with thousands of eligible counterparties in Eurosystem operations and a very wide range of eligible collateral. In practice, mitigating systemic arbitrage requires limiting this combination of large set of eligible banks and collateral. This can be done by implementing a primary dealer system, where only prime banks can borrow directly from Eurosystem, or confining the list of eligible collateral to assets of the highest quality. 


\section{References}

Abbassi, Puriya, Falk Bräuning, Falko Fecht, José-Luis Peydró, 2014, "Cross-border liquidity, relationships and monetary policy: evidence from the Euro area interbank crisis", Bundesbank Discussion paper 45/2014.

Acharya, Viral V., Sascha Steffen, 2015, "The greatest carry trade ever? Understanding eurozone bank risks," Journal of Financial Economics 115(2), pp. 215-236.

Bank for International Settlements, 2013, "Central bank collateral frameworks and practices, A report by a study group established by the markets committee," March, ISBN 92-9197-926-0 (online).

Bindseil, Ulrich, Kjell G. Nyborg, Ilya A. Strebulaev, 2009, "Repo Auctions and the Market for Liquidity," Journal of Money, Credit, and Banking 41, pp. 1391-1421.

Bindseil, Ulrich, 2014, Monetary policy operations and the financial system, Oxford University Press, Oxford.

Cassola, Nuno, Cornelia Holthausen, and Marco Lo Duca, 2010, "The 2007/2009 turmoil: a challenge for the integration of the euro area money market?", Working paper, European Central Bank.

Cochrane, John H., 2014, "Monetary policy with interest on reserves", Journal of Economic Dynamics and Control 49, pp. 74-108.

Diamond, Douglas W., Raghuram G. Rajan, 2011, "Fear of Fire Sales, Illiquidity Seeking, and Credit Freezes," Quarterly Journal of Economics 126(2), pp. 557-591.

Drechsler, Itamar, Thomas Drechsel, David Marques-Ibanez, Philipp Schnabl, 2013, "Who Borrows from the Lender of Last Resort?," Working paper, downloaded from http:// people.stern.nyu.edu/idrechsl/WhoBorrowsLOLR.pdf (29.01.2015).

Eberl, Jakob, Christopher Weber, 2014, "ECB Collateral Criteria: A Narrative Database 2001-2013," Ifo Working Paper, downloaded from https://ideas.repec.org/p/ces/ ifowps/_174.html (17.02.2015).

European Central Bank, 2003, "GUIDELINE OF THE EUROPEAN CENTRAL BANK of 1 December 2003 amending Guideline ECB/2000/7 on monetary policy instruments and procedures of the Eurosystem (ECB/2003/16)," Official Journal of the European Union L $69,8.3 .2004$, pp. $1-2 \& 31-47$.

European Central Bank, 2005, "GUIDELINE OF THE EUROPEAN CENTRAL BANK of 3 February 2005 amending Guideline ECB/2000/7 on monetary policy instruments and procedures of the Eurosystem (ECB/2005/2)," Official Journal of the European Union L $111,2.5 .2005$, pp. $1-2 \& 32-46$. 
European Central Bank, 2006, "GUIDELINE OF THE EUROPEAN CENTRAL BANK of 31 August 2006 amending Guideline ECB/2000/7 on monetary policy instruments and procedures of the Eurosystem (ECB/2006/12)," Official Journal of the European Union L 352, 13.12.2006, pp. 1-2 \& 35-56.

European Central Bank, 2008a, "REGULATION (EC) No 1053/2008 OF THE EUROPEAN CENTRAL BANK of 23 October 2008 on temporary changes to the rules relating to eligibility of collateral (ECB/2008/11)," Official Journal of the European Union L 282, 25.10.2008, pp. 17-18.

European Central Bank, 2008b, "GUIDELINE OF THE EUROPEAN CENTRAL BANK of 23 October 2008 amending Guideline ECB/2000/7 on monetary policy instruments and procedures of the Eurosystem (ECB/2008/13)," Official Journal of the European Union L 36, 5.2.2009, pp. 31-45.

European Central Bank, 2010, "GUIDELINE OF THE EUROPEAN CENTRAL BANK of 16 September 2010 amending Guideline ECB/2000/7 on Monetary Policy Instruments and Procedures of the Eurosystem (ECB/2010/13)," Official Journal of theEuropean Union L 267, 9.10.2010, pp. 21-55.

European Central Bank, 2012, "Indicators of market segmentation: Media request following the ECB press conference on 2 August 2012," https://www.ecb.europa.eu/pub/pdf/ other/is120802_media_request.en.pdf.

European Central Bank, 2014, "Annual report 2013," ISSN 1725-2865 (online).

European Parliament and Council, 2000, "DIRECTIVE 2000/12/EC OF THE EUROPEAN PARLIAMENT AND OF THE COUNCIL of 20 March 2000 relating to the taking up and pursuit of the business of credit institutions," Official Journal of the European Communities L 126, 26.5.2000.

Ewerhart, Christian, Jens Tapking, 2008, "Repo Markets, Counterparty Risk, and the 2007/2008 Liquidity Crisis," Working paper, Swiss Finance Institute, downloaded from http://papers.ssrn.com/sol3/papers.cfm?abstract_id=1138609\# (29.01.2015).

Fecht, Falko, Kjell G. Nyborg, Jörg Rocholl, 2011, "The price of liquidity: The effects of market conditions and bank characteristics," The Journal of Financial Economics 102, pp. 344-362.

Gabrieli, Silvia and Co-Pierre Georg, 2014, "A network view on interbank market freezes," Discussion paper 44, Deutsche Bundesbank.

Greene, William H., 2000, Econometric analysis, 4th edition, Prentice Hall, US.

Hackethal, Andreas, 2004, German banks and banking structure. In:Krahnen, J.P., Schmidt, R.H.(Eds.), The German Financial System. Oxford University Press, pp. 71-105. 
Heider, Florian, Marie Hoerova, and Cornelia Holthausen, 2009, "Liquidity hoarding and interbank market spreads: The role of counterparty risk," Working paper 1126, European Central Bank.

Jordan, Thomas J., 2012, "Some Lessons for Monetary Policy from the Recent Financial Crisis," International Journal of Central Banking 8(S1), pp. 289-292.

Knot, Klaas, 2013, Central bank independence and unconventional monetary policy: Challenges for the ECB, Speech at the Bank of Mexico international conference on 15 October 2013, downloaded from http://www.dnb.nl/en/binaries/EN\%20-\%20Speech $\% 20 \mathrm{Klaas} \%$ 20Knot $\% 20$ Central $\% 20$ bank $\% 20$ independence $\% 20$ and $\% 20$ unconventional $\% 20$ monetary $\%$ $\backslash 20$ policy_tcm47-298104.pdf (17.02.2015).

Nyborg, Kjell G., Ulrich Bindseil, Ilya A. Strebulaev, 2002, "Bidding and performance in repo auctions: evidence from ECB open market operations", Working paper No. 157, downloaded from http://www.ecb.europa.eu/pub/research/authors/profiles/ kjell-g-nyborg.en.html (17.02.2015).

Nyborg, Kjell G., 2015a, Collateral frameworks: The open secret of central banks, book manuscript, University of Zurich and Swiss Finance Institute.

Nyborg, Kjell G., 2015b, "Central Bank Collateral Frameworks," Working paper, University of Zurich and Swiss Finance Institute.

Van Rixtel, Adrian, Gabriele Gasperini, 2013, "Financial crises and bank funding: recent experience in the euro area," BIS Working Paper 406. 


\section{Table 1}

Eurosystem haircuts.

Eurosystem haircuts (in \%) for marketable collateral by liquidity category, residual maturity, and coupon (zero, fixed, or floating). Panel A: Applies from March 8, 2004 to December 31, 2006 for tier one marketable assets and, after the introduction of the "single list," for all marketable assets from January 1, 2007 to October 24, 2008. See Guideline of the European Central Bank (2003) for initial documentation of these haircuts and Guideline of the European Central Bank (2006) for the introduction of the single list. Panel B: Incorporates updates announced on October 23, 2008. Updates in blue slanted type and with a dagger ( $\dagger$ ) apply from October 25, 2008 (European Central Bank, 2008a). Those in red italic and starred $\left({ }^{*}\right)$ apply from February 1, 2009 (European Central Bank, 2008b). Nyborg (2015a) provides a further list of references showing the validity of the haircuts in both panels over the full periods listed here. Note that some marketable asset special cases as well as non-marketable assets are not covered by the table. See Nyborg (2015a) for details.

Panel A: Haircuts applied to marketable tier one assets (from March 8, 2004 to December 31, 2006) or all marketable assets (January 1, 2007 to October 24, 2008)

Category $I$

Central government debt instruments,

Debt instruments issued

by central banks

\section{Liquidity categories}

\section{Category II}

Local and regional government debt instruments,

Jumbo Pfandbrief-style debt instruments,

Agency debt instruments,

Supranational debt instruments

\section{Category III}

Traditional Pfandbrief-

style debt instruments,

Credit institution debt

instruments,

Debt instruments issued by

corporate and other issuers

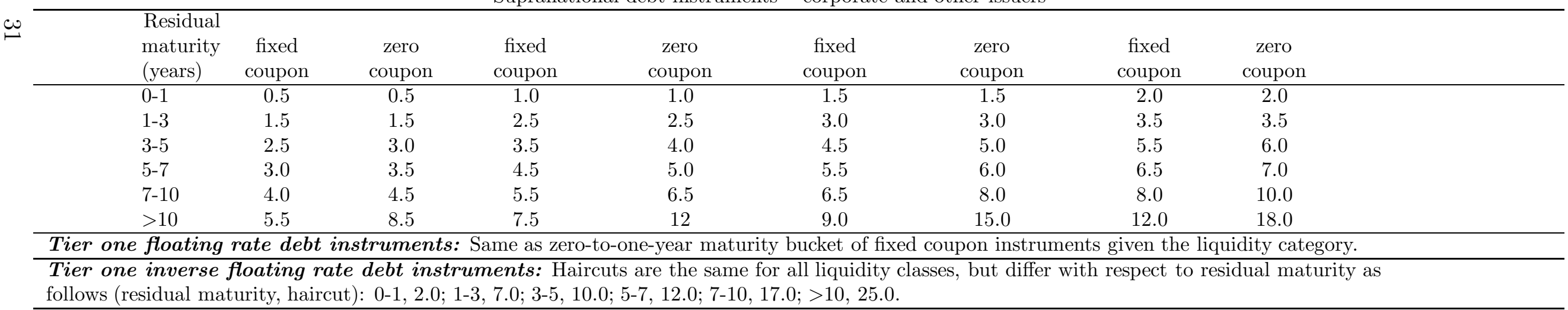


Table 1 - continued

Panel B: Haircuts applied to eligible marketable assets (from October 25, 2008 to December 31, 2010)

\section{Category I}

Central government debt instruments,

Debt instruments issued

by central banks

Liquidity categories for marketable assets

\section{Category II}

Local and regional government debt instruments,

Jumbo covered bank bonds,

Agency debt instruments,

Supranational debt instruments

\section{Category $I V^{*}$}

Traditional covered bank bonds, Credit institution debt

Debt instruments issued by

corporate and other issuers instruments (unsecured)
Category $V^{*}$

Asset-backed securities*

\begin{tabular}{|c|c|c|c|c|c|c|c|c|c|c|}
\hline $\begin{array}{l}\text { Credit } \\
\text { quality }^{\dagger}\end{array}$ & $\begin{array}{r}\text { Residual } \\
\text { maturity } \\
\text { (years) }\end{array}$ & $\begin{array}{c}\text { fixed } \\
\text { coupon }\end{array}$ & $\begin{array}{c}\text { zero } \\
\text { coupon }\end{array}$ & $\begin{array}{c}\text { fixed } \\
\text { coupon }\end{array}$ & $\begin{array}{c}\text { zero } \\
\text { coupon }\end{array}$ & $\begin{array}{c}\text { fixed } \\
\text { coupon }\end{array}$ & $\begin{array}{c}\text { zero } \\
\text { coupon }\end{array}$ & $\begin{array}{c}\text { fixed } \\
\text { coupon }\end{array}$ & $\begin{array}{c}\text { zero } \\
\text { coupon }\end{array}$ & \\
\hline \multirow{6}{*}{$\begin{array}{l}A A A \\
\text { to } A-^{\dagger}\end{array}$} & $0-1$ & 0.5 & 0.5 & 1.0 & 1.0 & 1.5 & 1.5 & $6.5^{*}$ & $6.5^{*}$ & \multirow{6}{*}{$12^{*}$} \\
\hline & $1-3$ & 1.5 & 1.5 & 2.5 & 2.5 & 3.0 & 3.0 & $8.0^{*}$ & $8.0^{*}$ & \\
\hline & $3-5$ & 2.5 & 3.0 & 3.5 & 4.0 & 4.5 & 5.0 & $9.5^{*}$ & $10.0^{*}$ & \\
\hline & $5-7$ & 3.0 & 3.5 & 4.5 & 5.0 & 5.5 & 6.0 & $10.5^{*}$ & $11.0^{*}$ & \\
\hline & $7-10$ & 4.0 & 4.5 & 5.5 & 6.5 & 6.5 & 8.0 & $11.5^{*}$ & $13.0^{*}$ & \\
\hline & $>10$ & 5.5 & 8.5 & 7.5 & 12.0 & 9.0 & 15.0 & $14.0^{*}$ & $20.0^{*}$ & \\
\hline
\end{tabular}

Floating rate debt instruments: For liquidity categories I to IV ${ }^{*}$, same as in Panel A.

Inverse floating rate debt instruments: For liquidity categories I to $I V^{*}$ same as in Panel $A$.

$\mathrm{BBB}+$ to $\mathrm{BBB-} \mathbf{-}^{\dagger}$

Add $5 \%$ to $A A A$ to $A$ - according to residual maturity, coupon structure and liquidity category except for $A B S$ for which $B B B$ - to BBB+ is not eligible. ${ }^{\dagger}$ 


\section{Table 2}

Aggregate collateral amount and liquidity uptake patterns from January 2006 to December 2010.

This table reports on various features of the aggregate collateral pool (of German banks) over time. Statistics are provided for the whole sample period (January 18, 2006 to December 31, 2010) as well as for five sub-periods: "2006", "Pre-Crisis", "Crisis to Lehman", "Post-Lehman", and "2010", with dates as shown below. The whole sample period covers 60 maintenance periods. We observe at least one day in each maintenance period. Values of each variable are first averaged within each maintenance period. The reported numbers are averages of these maintenance period mean values (there are two exceptions to this procedure-both in Panel A).

Panel A: Collateral and credit are the aggregated collateral values and liquidity uptakes, respectively. The Euroystem liquidity uptake is taken from the ECB's webpage, http://sdw.ecb.europa.eu/browse.do?node=bbn129). "Coverage ratio, Germany" is collateral divided by credit in Germany, calculated from the numbers in the table, except for the total sample period where the ratio is a quantity weighted average of the sub-period values in the table (weights: number of maintenance periods). "Credit ratio Germany/Eurosystem" is German liquidity uptake as a fraction of the total Eurosystem uptake, calculated from the numbers in the table (the total sample period ratio is calculated as for the coverage ratio).

Panel B shows collateral pool weights of (1) different collateral types, (2) the issuers' country of residence, and (3) of own-use collateral. Types are Government, Covered, Corporates, and "Uncovered etc.". Country of residence is either Germany or PIIGSC (Portugal, Ireland, Italy, Greece, Spain, and Cyprus). Own-use refers to collateral issued by an entity with which the bank that holds it in the pool has "close links" (European Central Bank, 2005, and European Central Bank, 2010).

Panel $\mathrm{C}$ shows excess collateral ratios calculated as (collateral value - excluded collateral - credit)/(collateral value excluded collateral). First, we take all collateral into account (no subset is excluded). Second, we exclude "non-German" collateral, third, "Uncovered etc.", and fourth, the latter together with collateral of PIIGSC issuers.

\begin{tabular}{|c|c|c|c|c|c|c|c|}
\hline & & $\begin{array}{r}\text { Total } \\
18.01 .06 \\
31.12 .10\end{array}$ & $\begin{array}{r}\mathbf{2 0 0 6} \\
18.01 .06 \\
16.01 .07\end{array}$ & $\begin{array}{r}\text { Pre- } \\
\text { Crisis } \\
17.01 .07 \\
07.08 .07\end{array}$ & $\begin{array}{r}\text { Crisis to } \\
\text { Lehman } \\
08.08 .07 \\
09.09 .08\end{array}$ & $\begin{array}{r}\begin{array}{r}\text { Post- } \\
\text { Lehman }\end{array} \\
16.09 .08 \\
19.01 .10\end{array}$ & $\begin{array}{r}\mathbf{2 0 1 0} \\
20.01 .10 \\
31.12 .10\end{array}$ \\
\hline Number of banks $(\min -\max )$ & & $45-1,387$ & $864-981$ & $202-859$ & $203-862$ & $801-1,387$ & $45-1,383$ \\
\hline Number of maintenance periods & & 60 & 12 & 7 & 13 & 16 & 12 \\
\hline Number of observed days & & 667 & 21 & 14 & 113 & 278 & 241 \\
\hline \multicolumn{8}{|c|}{ Panel A: Collateral and liquidity uptake } \\
\hline Collateral, Germany & mEUR & 616,517 & 494,536 & 516,887 & 596,291 & 728,599 & 669,086 \\
\hline Credit, Germany & mEUR & 206,483 & 233,027 & 233,775 & 199,499 & 222,966 & 149,606 \\
\hline Credit, Eurosystem & mEUR & 555,567 & 424,141 & 434,663 & 461,690 & 710,135 & 653,133 \\
\hline Coverage ratio, Germany & $\%$ & 3.10 & 2.12 & 2.21 & 2.99 & 3.27 & 4.47 \\
\hline Credit ratio Germany/Eurosystem & $\%$ & 39.58 & 54.94 & 53.78 & 43.21 & 31.40 & 22.91 \\
\hline \multicolumn{8}{|l|}{ Panel B: Collateral pool weights } \\
\hline Government* & $\%$ & 16.60 & 20.13 & 15.46 & 14.39 & 13.54 & 20.21 \\
\hline Covered** & $\%$ & 22.60 & 28.03 & 24.62 & 22.13 & 20.88 & 18.81 \\
\hline Corporates & $\%$ & 6.50 & 5.75 & 6.76 & 7.04 & 6.80 & 6.09 \\
\hline Uncovered etc. & $\%$ & 54.29 & 46.09 & 53.16 & 56.44 & 58.75 & 54.87 \\
\hline Germany & $\%$ & 54.49 & 55.21 & 46.98 & 45.03 & 58.51 & 63.04 \\
\hline PIIGSC & $\%$ & 20.92 & 21.28 & 25.39 & 27.25 & 19.08 & 13.54 \\
\hline Own-use & $\%$ & 6.47 & 1.71 & 1.40 & 1.38 & 11.12 & 13.51 \\
\hline \multicolumn{8}{|c|}{ Panel C: Excess collateral given different exclude subsets } \\
\hline Nothing excluded & $\%$ & 65.47 & 52.90 & 54.67 & 66.59 & 69.34 & 77.95 \\
\hline Excl. Non-German & $\%$ & 34.27 & 14.44 & 3.04 & 25.66 & 46.82 & 64.91 \\
\hline Excl. Uncovered etc. & $\%$ & 24.64 & 12.49 & 3.09 & 23.28 & 25.64 & 49.50 \\
\hline Excl. Uncovered etc. + PIIGSC & $\%$ & 3.84 & -11.65 & -28.03 & -3.33 & 3.66 & 45.95 \\
\hline
\end{tabular}

* By central, regional or local governments, or central banks, agencies, or supranationally issued debt instruments

** Traditional and jumbo covered bank bonds 
Table 3

Descriptive statistics: per sub-period and for the full sample period.

Descriptive statistics for normalized credit, collateral quality, financial health, normalized deposit flows, and concentration measures. The population is equally weighted averages across maintenance periods for each bank and sub-period (or the total sample period). Panel A covers the "Pre-Crisis", Panel B the "Early Crisis", Panel C the "Full Allotment", and Panel D the full period. "SE" is standard errors. "SD" is standard deviation. "Med34" is either the average of the four observations around the median if the number of observed banks is even or, else, of the three observations around the median. "Min3" is the average of the smallest three observations. "Max3" is the equivalent for the largest three observations. "Number of banks" shows counts in total and by banking groups. "Head" institutions are Landesbanks and Cooperative central banks.

The logarithm of total book assets measures bank size. Credit is normalized either by total assets, with assets taken from end-of-month preceding each maintenance period, or by average daily reserve requirements in each maintenance period. Collateral quality measures are collateral haircut, duration, probability of default, liquidity category, and the fraction of own use collateral. Financial health measures are equity ratio, write-offs \& provisions, and ROA. Equity ratio is equity divided by total assets, both taken from end-of-month preceding each maintenance period. Write-offs and provisions (ROA) are given as preceding year's write-offs and provisions (income) divided by total assets, where assets are taken from the beginning of the preceding year. Deposit flows are contemporaneous and normalized in the same manner as credit is normalized. Deposit flows are separated into flows of banks and flows of non-banks. Concentration measures are the Herfindahl-Indices for collateral classes and issuer groups.

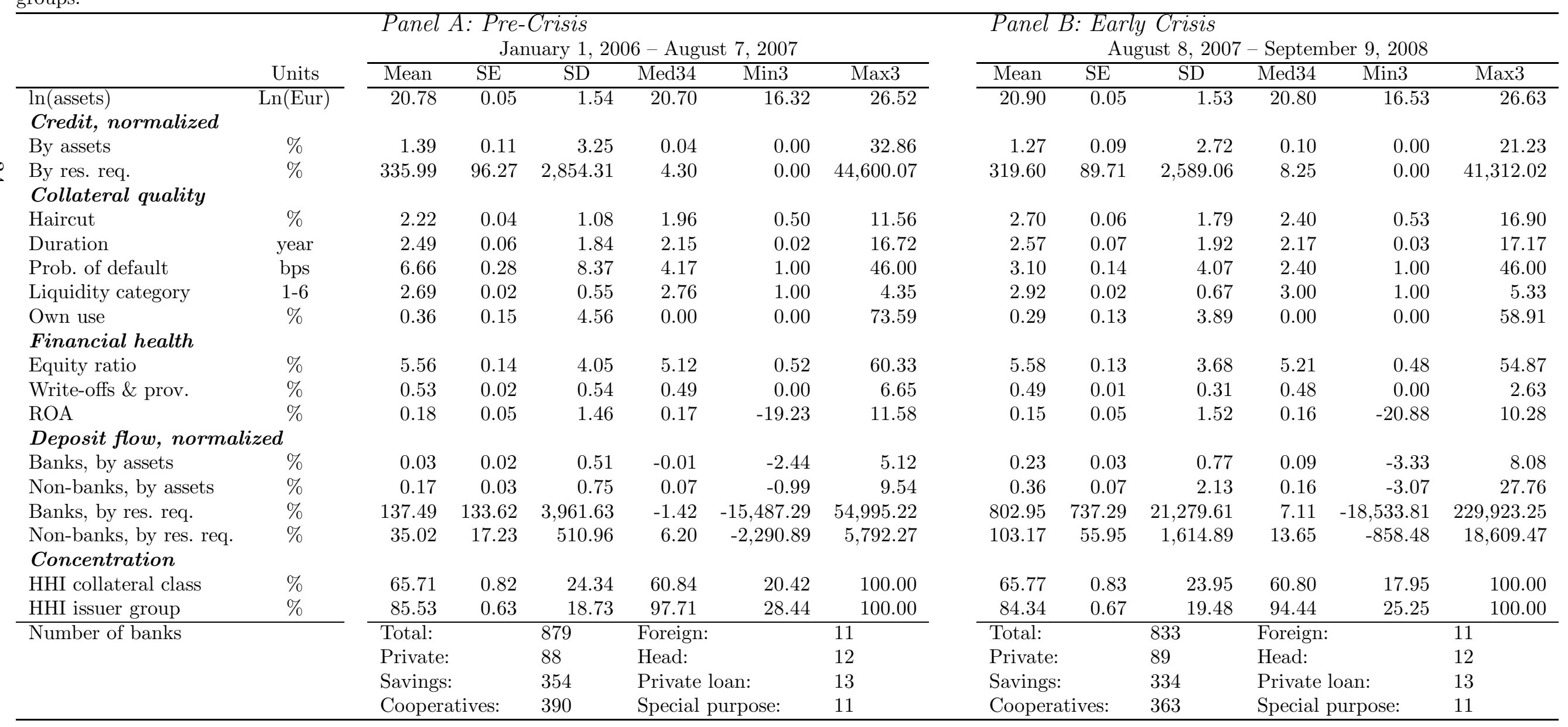


Table 3 - continued

Panel C: Full Allotment

\begin{tabular}{|c|c|c|c|c|c|c|c|}
\hline & \multirow[b]{2}{*}{ Units } & \multicolumn{6}{|c|}{ November 12, 2008 - November 9, 2010} \\
\hline & & Mean & $\mathrm{SE}$ & $\mathrm{SD}$ & Med34 & Min3 & Max3 \\
\hline $\ln ($ assets $)$ & Ln(Eur) & 20.51 & 0.04 & 1.46 & 20.37 & 16.60 & 26.71 \\
\hline \multicolumn{8}{|l|}{ Credit, normalized } \\
\hline By assets & $\%$ & 2.60 & 0.08 & 2.88 & 1.82 & 0.00 & 23.32 \\
\hline By res. req. & $\%$ & 409.52 & 79.54 & $2,906.12$ & 145.15 & 0.00 & $50,974.22$ \\
\hline \multicolumn{8}{|l|}{ Collateral quality } \\
\hline Haircut & $\%$ & 5.89 & 0.06 & 2.12 & 5.96 & 0.71 & 18.06 \\
\hline Duration & year & 2.79 & 0.05 & 1.96 & 2.42 & 0.07 & 25.92 \\
\hline Prob. of default & bps & 3.76 & 0.06 & 2.09 & 3.60 & 1.00 & 19.39 \\
\hline Liquidity category & $1-6$ & 3.35 & 0.02 & 0.60 & 3.45 & 1.01 & 5.29 \\
\hline Own use & $\%$ & 0.83 & 0.20 & 7.28 & 0.00 & 0.00 & 99.41 \\
\hline \multicolumn{8}{|l|}{ Financial health } \\
\hline Equity ratio & $\%$ & 5.56 & 0.07 & 2.69 & 5.25 & 0.45 & 41.80 \\
\hline Write-offs \& prov. & $\%$ & 0.45 & 0.01 & 0.30 & 0.41 & 0.00 & 2.76 \\
\hline $\mathrm{ROA}$ & $\%$ & 0.05 & 0.06 & 2.24 & 0.15 & -41.28 & 8.74 \\
\hline \multicolumn{8}{|c|}{ Deposit flow, normalized } \\
\hline Banks, by assets & $\%$ & 0.08 & 0.06 & 2.13 & -0.01 & -6.79 & 34.66 \\
\hline Non-banks, by assets & $\%$ & 0.30 & 0.02 & 0.58 & 0.23 & -2.81 & 5.96 \\
\hline Banks, by res. req. & $\%$ & 99.25 & 149.80 & $5,473.51$ & -1.40 & $-40,403.55$ & $80,297.18$ \\
\hline $\begin{array}{l}\text { Non-banks, by res. req. } \\
\text { Concentration }\end{array}$ & $\%$ & 9.07 & 8.45 & 308.56 & 18.78 & $-6,060.81$ & $1,037.90$ \\
\hline HHI collateral class & $\%$ & 63.73 & 0.62 & 22.60 & 60.68 & 20.70 & 100.00 \\
\hline HHI issuer group & $\%$ & 79.61 & 0.53 & 19.25 & 83.08 & 30.02 & 100.00 \\
\hline \multirow[t]{4}{*}{ Number of banks } & & \multicolumn{2}{|l|}{ Total: } & 1,335 & \multicolumn{2}{|l|}{ Foreign: } & 11 \\
\hline & & \multicolumn{2}{|l|}{ Private: } & 106 & \multicolumn{2}{|l|}{ Head: } & 12 \\
\hline & & \multicolumn{2}{|l|}{ Savings: } & 408 & \multicolumn{2}{|c|}{ Private loan: } & 13 \\
\hline & & \multicolumn{2}{|c|}{ Cooperatives: } & 774 & \multicolumn{2}{|c|}{ Special purpose: } & 11 \\
\hline
\end{tabular}

Panel D: Full Period

\begin{tabular}{|c|c|c|c|c|c|}
\hline Mean & $\overline{\mathrm{SE}}$ & SD & Med34 & Min3 & Max3 \\
\hline 20.45 & 0.04 & 1.45 & 20.32 & 16.52 & 26.62 \\
\hline 2.16 & 0.07 & 2.59 & 1.41 & 0.00 & 22.30 \\
\hline 366.15 & 75.70 & $2,791.59$ & 116.76 & 0.00 & $47,301.43$ \\
\hline 4.78 & 0.06 & 2.07 & 4.30 & 0.78 & 15.26 \\
\hline 2.68 & 0.05 & 1.68 & 2.33 & 0.05 & 17.91 \\
\hline 4.34 & 0.09 & 3.27 & 3.86 & 1.00 & 39.24 \\
\hline 3.18 & 0.02 & 0.59 & 3.21 & 1.00 & 5.01 \\
\hline 0.61 & 0.16 & 5.84 & 0.00 & 0.00 & 99.41 \\
\hline 5.63 & 0.09 & 3.21 & 5.27 & 0.48 & 56.79 \\
\hline 0.47 & 0.01 & 0.29 & 0.45 & 0.00 & 3.35 \\
\hline 0.08 & 0.06 & 2.23 & 0.16 & -38.41 & 12.49 \\
\hline 0.07 & 0.02 & 0.60 & 0.01 & -2.04 & 9.68 \\
\hline 0.29 & 0.02 & 0.61 & 0.18 & -1.32 & 8.11 \\
\hline 199.67 & 169.30 & $6,243.42$ & 0.18 & $-8,565.04$ & $94,637.31$ \\
\hline 26.95 & 6.77 & 249.57 & 15.48 & $-2,547.89$ & $3,462.38$ \\
\hline 66.13 & 0.56 & 20.59 & 64.09 & 21.46 & 100.00 \\
\hline 82.46 & 0.46 & 16.94 & 86.20 & 32.05 & 100.00 \\
\hline Total: & & 1,360 & \multicolumn{2}{|l|}{ Foreign: } & 12 \\
\hline Private: & & 107 & \multicolumn{2}{|l|}{ Head: } & 12 \\
\hline Savings: & & 416 & \multicolumn{2}{|c|}{ Private loan: } & 13 \\
\hline Coopera & tives: & 789 & \multicolumn{2}{|c|}{ Special purpose: } & 11 \\
\hline
\end{tabular}

*not covering September 10 - November 11, 2008 
Table 4

Averages by bank size groups: per sub-period and the full sample period.

Averages of normalized credit, collateral quality, financial health, normalized deposit flows, and concentration measures by bank size groups. The population is equally weighted averages across maintenance periods for each bank and sub-period (or the total sample period). Panel A covers the "Pre-Crisis", Panel B the "Early Crisis", Panel C the "Full Allotment", and Panel D the full period. We build five size groups according to the 25, 50, 75, and 99 percentiles by averaging each bank's total assets across all 56 maintenance periods: $<25 \%, 25-50 \%, 50-75 \%, 75-99 \%$, and $>99 \%$. A bank does therefore not change its size group from one sub-period to another. A bank in size group 25-50\%, for instance, has average size larger than the $25^{\text {th }}$ and smaller than or equal to the $50^{t h}$ percentile.

The logarithm of total book assets measures bank size. Credit is normalized either by total assets, taken from end-of-month preceding each maintenance period, or by average daily reserve requirements in each maintenance period. Collateral quality measures are haircut, duration, probability of default, liquidity category, and the fraction of own use collateral. Financial health is measured by equity ratio, write-offs \& provisions, and ROA. Equity ratio is equity divided by total assets, both taken from end-of-month preceding each maintenance period. Write-offs and provisions (ROA) are given as preceding year's write-offs and provisions (income) divided by total assets, where assets are taken from the beginning of the preceding year. Deposit flows are contemporaneous and normalized in the same manner as credit is normalized. Deposit flows are separated into flows of banks and flows of non-banks. Concentration measures are the Herfindahl-Indices for collateral classes and issuer groups. "n.a." indicates that data is not available.

\begin{tabular}{|c|c|c|c|c|c|c|c|c|c|c|c|}
\hline & \multicolumn{5}{|c|}{$\begin{array}{l}\text { Panel A: Pre-Crisis } \\
\quad \text { January } 1,2006 \text { - August } 7,2007\end{array}$} & \multicolumn{5}{|c|}{$\begin{array}{l}\text { Panel B: Early Crisis } \\
\text { August } 8,2007 \text { - September } 9,2008\end{array}$} \\
\hline & & \multicolumn{5}{|c|}{ Size groups } & \multicolumn{5}{|c|}{ Size groups } \\
\hline & & $<25 \%$ & $25-50 \%$ & $50-75 \%$ & $75-99 \%$ & $>99 \%$ & $<25 \%$ & $25-50 \%$ & $50-75 \%$ & $75-99 \%$ & $>99 \%$ \\
\hline $\ln$ (assets) & Ln(Eur) & 18.67 & 19.84 & 20.68 & 22.15 & 26.01 & 18.77 & 19.88 & 20.73 & 22.21 & 26.11 \\
\hline \multicolumn{12}{|l|}{ Credit, normalized } \\
\hline By assets & $\%$ & 0.59 & 0.93 & 1.37 & 1.96 & 3.17 & 0.48 & 1.07 & 1.33 & 1.59 & 2.57 \\
\hline By res. req. & $\%$ & 53.20 & 366.15 & 128.51 & 598.85 & 977.21 & 42.02 & 300.82 & 126.66 & 583.85 & 597.44 \\
\hline \multicolumn{12}{|l|}{ Collateral quality } \\
\hline Haircut & $\%$ & 2.12 & 2.14 & 2.13 & 2.38 & 2.58 & 2.57 & 2.64 & 2.45 & 2.96 & 3.44 \\
\hline Duration & year & 2.08 & 2.17 & 2.24 & 2.99 & 4.48 & 2.23 & 2.37 & 2.20 & 2.99 & 5.01 \\
\hline Prob. of default & bps & 6.97 & 7.95 & 7.05 & 5.61 & 3.59 & 3.48 & 3.77 & 3.05 & 2.61 & 3.31 \\
\hline Liquidity category & $1-6$ & 2.70 & 2.61 & 2.61 & 2.79 & 2.94 & 2.96 & 2.90 & 2.81 & 2.99 & 3.35 \\
\hline Own use & $\%$ & n.a. & n.a. & 0.09 & 0.40 & 5.49 & n.a. & n.a. & 0.12 & 0.46 & 5.83 \\
\hline \multicolumn{12}{|l|}{ Financial health } \\
\hline Equity ratio & $\%$ & 7.07 & 6.03 & 5.29 & 4.85 & 4.34 & 7.20 & 5.92 & 5.43 & 4.91 & 4.24 \\
\hline Write-offs \& prov. & $\%$ & 0.51 & 0.55 & 0.59 & 0.50 & 0.17 & 0.47 & 0.55 & 0.52 & 0.46 & 0.29 \\
\hline ROA & $\%$ & -0.04 & 0.24 & 0.20 & 0.22 & 0.13 & -0.14 & 0.23 & 0.19 & 0.19 & 0.19 \\
\hline \multicolumn{12}{|c|}{ Deposit flow, normalized } \\
\hline Banks, by assets & $\%$ & 0.01 & -0.01 & 0.03 & 0.04 & 0.25 & 0.10 & 0.29 & 0.25 & 0.21 & 0.46 \\
\hline Non-banks, by assets & $\%$ & 0.23 & 0.10 & 0.09 & 0.25 & 0.09 & 0.23 & 0.22 & 0.59 & 0.30 & 0.37 \\
\hline Banks, by res. req. & $\%$ & -11.81 & -120.92 & 320.23 & 203.91 & 111.18 & 7.45 & 29.27 & -201.63 & 2360.49 & 540.48 \\
\hline $\begin{array}{l}\text { Non-banks, by res. req. } \\
\text { Concentration }\end{array}$ & $\%$ & 116.12 & 5.54 & -12.12 & 53.47 & 21.00 & 18.82 & 18.41 & 40.35 & 223.41 & 322.68 \\
\hline HHI collateral class & $\%$ & 79.33 & 71.41 & 64.27 & 58.28 & 41.58 & 78.65 & 71.75 & 66.43 & 57.93 & 39.80 \\
\hline HHI issuer group & $\%$ & 92.58 & 88.60 & 84.92 & 82.10 & 60.02 & 93.47 & 86.78 & 85.46 & 79.81 & 53.73 \\
\hline Number of banks & & 143 & 171 & 252 & 299 & 14 & 122 & 162 & 237 & 298 & 14 \\
\hline
\end{tabular}


Panel C: Full Allotment

November 12, 2008 - November 9, 2010

\begin{tabular}{lrrrr}
\hline \multicolumn{5}{c}{ Size groups } \\
$<25 \%$ & $25-50 \%$ & $50-75 \%$ & $75-99 \%$ & $>99 \%$ \\
\hline
\end{tabular}

\begin{tabular}{lc}
\hline $\ln ($ assets) & Ln(Eur) \\
Credit, normalized & $\%$ \\
By assets & $\%$ \\
By res. req. & \\
Collateral quality & $\%$ \\
Haircut & year \\
Duration & $\mathrm{bps}$ \\
Prob. of default & $1-6$ \\
Liquidity category & $\%$ \\
Own use & \\
Financial health & $\%$ \\
Equity ratio & $\%$ \\
Write-offs \& prov. & $\%$ \\
ROA & $\%$ \\
Deposit flow, $\boldsymbol{n o r m a l i z e d}$ \\
Banks, by assets & $\%$ \\
Non-banks, by assets & $\%$ \\
Banks, by res. req. & $\%$ \\
Non-banks, by res. req. & $\%$ \\
Concentration & $\%$ \\
HHI collateral class & $\%$ \\
HHI issuer group & \\
\hline Number of banks &
\end{tabular}

$\begin{array}{lllll}2.42 & 2.82 & 2.69 & 2.50 & 1.61\end{array}$

204.68

262.60

526.43

$646.17 \quad 423.06$

6.33

$6.21 \quad 5.53$

2.72

$5.38 \quad 8.51$

4.12

4.18

3.48

2.99

3.18

3.43

3.44

3.27

0.50

3.26

5.91

5.52

n.a.

5.72

6.45

0.42

0.47

5.34

0.48

$4.78 \quad 4.58$

0.01

0.01

0.15

0.44

0.01

$\begin{array}{lllll}0.27 & 0.02 & 0.09 & -0.03 & -0.29\end{array}$

$\begin{array}{lllll}36.86 & -52.22 & -294.86 & 731.16 & -80.08\end{array}$

$\begin{array}{lllll}23.82 & 24.19 & 11.56 & -22.19 & -30.32\end{array}$

$\begin{array}{lllll}73.81 & 67.39 & 62.02 & 52.64 & 39.60\end{array}$

\begin{tabular}{lllll}
83.08 & 80.42 & 80.42 & 75.72 & 50.21 \\
\hline
\end{tabular}

\begin{tabular}{rrrrr}
$<25 \%$ & $25-50 \%$ & $50-75 \%$ & $75-99 \%$ & $>99 \%$ \\
\hline 18.84 & 19.95 & 20.80 & 22.21 & 26.17
\end{tabular}

$\begin{array}{rrrrr}0.29 & 0.33 & 0.35 & 0.24 & 0.04\end{array}$
Panel D: Full Period

January 1, 2006 - November 9, 2010*

\begin{tabular}{lllll}
\hline \multicolumn{5}{c}{ Size groups } \\
$<25 \%$ & $25-50 \%$ & $50-75 \%$ & $75-99 \%$ & $>99 \%$ \\
\hline
\end{tabular}

\begin{tabular}{rrrrr}
$<25 \%$ & $25-50 \%$ & $50-75 \%$ & $75-99 \%$ & $>99 \%$ \\
\hline 18.81 & 19.91 & 20.75 & 22.16 & 26.10 \\
& & & & \\
2.03 & 2.33 & 2.14 & 2.11 & 2.36 \\
171.49 & 275.66 & 474.89 & 537.97 & 649.33 \\
& & & & \\
5.50 & 5.27 & 4.26 & 4.06 & 5.24 \\
2.55 & 2.52 & 2.52 & 3.04 & 5.17 \\
4.48 & 4.85 & 4.25 & 3.77 & 4.22 \\
3.31 & 3.27 & 3.05 & 3.07 & 3.42 \\
n.a. & n.a. & 0.46 & 1.61 & 7.54 \\
& & & & \\
6.47 & 5.82 & 5.31 & 4.94 & 4.42 \\
0.44 & 0.49 & 0.51 & 0.46 & 0.33 \\
0.05 & 0.03 & 0.18 & 0.09 & 0.08 \\
& & & & \\
0.09 & 0.05 & 0.10 & 0.05 & 0.05 \\
0.28 & 0.29 & 0.32 & 0.26 & 0.13 \\
8.01 & -38.44 & -16.26 & 878.54 & 73.39 \\
30.53 & 21.83 & 3.26 & 53.01 & 33.24 \\
& & & & \\
75.78 & 69.37 & 64.29 & 55.71 & 40.20 \\
85.58 & 83.35 & 83.24 & 78.66 & 54.23 \\
\hline 340 & 340 & 340 & 326 & 14 \\
\hline
\end{tabular}

${ }^{*}$ not covering Sept. 10 - Nov. 11, 2008 
Table 5

Panel regressions of haircut on size and financial health.

Each column represents a separate regression carried out on the population of bank-maintenance period observations. The first four columns show regressions for the "Pre-Crisis", the "Early Crisis", the "Full Allotment", and the total period with Huber-White corrected standard errors. Columns five to eight show the same regressions with standard errors clustered on banks. All regressions include maintenance period and banking group fixed effects. Base category for the banking groups is "Private banks". $t$-statistics are in brackets underneath the coefficients. $a, b$, and $c$ denote significance (two-tailed) at $1 \%, 5 \%$, and $10 \%$ level, respectively. For the period labelled "Total," note that observations in the period September 10 to November 11, 2008, are dropped.

The dependent variable is haircut (in percent). For variables subscripted by $m-1$ and $y-1$, values are taken from end-of-month and end-of-year preceding each maintenance period, respectively. Ln(assets) measures bank size. Financial health is measured by equity ratio, write-offs \& provisions, and ROA.

\begin{tabular}{|c|c|c|c|c|c|c|c|c|c|}
\hline & \multicolumn{4}{|c|}{ Panel, Huber-White SEs } & \multicolumn{4}{|c|}{ Panel, with clustering on banks } \\
\hline & & $\begin{array}{c}\text { Pre-Crisis } \\
18.01 .06- \\
07.08 .07\end{array}$ & $\begin{array}{c}\text { Early Crisis } \\
08.08 .07- \\
09.09 .08\end{array}$ & $\begin{array}{c}\text { Full Allot. } \\
12.11 .08- \\
09.11 .10\end{array}$ & $\begin{array}{c}\text { Total } \\
18.01 .06- \\
09.11 .10\end{array}$ & $\begin{array}{c}\text { Pre-Crisis } \\
18.01 .06- \\
07.08 .07\end{array}$ & $\begin{array}{c}\text { Early Crisis } \\
08.08 .07- \\
09.09 .08\end{array}$ & $\begin{array}{c}\text { Full Allot. } \\
12.11 .08- \\
09.11 .10\end{array}$ & $\begin{array}{c}\text { Total } \\
18.01 .06 \\
09.11 .10\end{array}$ \\
\hline $\ln (\text { assets })_{m-1}$ & $\ln$ (Eur) & $\begin{array}{c}0.083^{a} \\
(8.44)\end{array}$ & $\begin{array}{c}0.100^{a} \\
(5.21)\end{array}$ & $\begin{array}{c}-0.083^{a} \\
(-5.31)\end{array}$ & $\begin{array}{l}-0.004 \\
(-0.45)\end{array}$ & $\begin{array}{l}0.083^{b} \\
(2.26)\end{array}$ & $\begin{array}{l}0.100 \\
(1.53)\end{array}$ & $\begin{array}{l}-0.083 \\
(-1.19)\end{array}$ & $\begin{array}{l}-0.004 \\
(-0.08)\end{array}$ \\
\hline Equity ratio $_{m-1}$ & $\%$ & $\begin{array}{c}-0.009^{a} \\
(-3.72)\end{array}$ & $\begin{array}{c}-0.028^{a} \\
(-4.07)\end{array}$ & $\begin{array}{c}-0.034^{a} \\
(-4.56)\end{array}$ & $\begin{array}{c}-0.020^{a} \\
(-5.72)\end{array}$ & $\begin{array}{l}-0.009 \\
(-1.01)\end{array}$ & $\begin{array}{c}-0.028^{c} \\
(-1.69)\end{array}$ & $\begin{array}{l}-0.034 \\
(-1.31)\end{array}$ & $\begin{array}{l}-0.020 \\
(-1.42)\end{array}$ \\
\hline Write-offs \& $\operatorname{prov}_{y-1}$ & $\%$ & $\begin{array}{c}-0.057^{a} \\
(-6.61)\end{array}$ & $\begin{array}{l}0.064 \\
(1.21)\end{array}$ & $\begin{array}{c}0.124^{a} \\
(3.33)\end{array}$ & $\begin{array}{l}-0.000 \\
(-0.00)\end{array}$ & $\begin{array}{l}-0.057^{b} \\
(-2.43)\end{array}$ & $\begin{array}{l}0.064 \\
(0.41)\end{array}$ & $\begin{array}{l}0.124 \\
(0.87)\end{array}$ & $\begin{array}{l}-0.000 \\
(-0.00)\end{array}$ \\
\hline $\mathrm{ROA}_{y-1}$ & $\%$ & $\begin{array}{c}-0.024^{a} \\
(-3.24)\end{array}$ & $\begin{array}{c}-0.027^{a} \\
(-3.51)\end{array}$ & $\begin{array}{l}-0.012 \\
(-0.83)\end{array}$ & $\begin{array}{l}-0.006 \\
(-0.81)\end{array}$ & $\begin{array}{l}-0.024 \\
(-0.85)\end{array}$ & $\begin{array}{l}-0.027 \\
(-1.23)\end{array}$ & $\begin{array}{l}-0.012 \\
(-0.25)\end{array}$ & $\begin{array}{l}-0.006 \\
(-0.25)\end{array}$ \\
\hline Savings banks & & $\begin{array}{c}-0.318^{a} \\
(-6.02)\end{array}$ & $\begin{array}{l}-0.106 \\
(-1.25)\end{array}$ & $\begin{array}{c}0.159^{b} \\
(2.06)\end{array}$ & $\begin{array}{l}-0.068 \\
(-1.55)\end{array}$ & $\begin{array}{l}-0.318 \\
(-1.49)\end{array}$ & $\begin{array}{l}-0.106 \\
(-0.37)\end{array}$ & $\begin{array}{l}0.159 \\
(0.47)\end{array}$ & $\begin{array}{l}-0.068 \\
(-0.27)\end{array}$ \\
\hline Cooperatives & & $\begin{array}{c}-0.123^{b} \\
-2.52)\end{array}$ & $\begin{array}{l}-0.014 \\
(-0.19)\end{array}$ & $\begin{array}{l}1.118^{a} \\
(15.51)\end{array}$ & $\begin{array}{c}0.533^{a} \\
(12.96)\end{array}$ & $\begin{array}{l}-0.123 \\
(-0.63)\end{array}$ & $\begin{array}{l}-0.014 \\
(-0.06)\end{array}$ & $\begin{array}{l}1.118^{a} \\
(3.62)\end{array}$ & $\begin{array}{c}0.533^{b} \\
(2.39)\end{array}$ \\
\hline Foreign banks & & $\begin{array}{c}-0.630^{a} \\
(-6.66)\end{array}$ & $\begin{array}{l}0.094 \\
(0.28)\end{array}$ & $\begin{array}{l}-0.241 \\
(-1.08)\end{array}$ & $\begin{array}{c}-0.281^{b} \\
(-2.17)\end{array}$ & $\begin{array}{l}-0.630^{b} \\
(-2.08)\end{array}$ & $\begin{array}{l}0.094 \\
(0.08)\end{array}$ & $\begin{array}{l}-0.241 \\
(-0.26)\end{array}$ & $\begin{array}{l}-0.281 \\
(-0.47)\end{array}$ \\
\hline Landesbanks & & $\begin{array}{c}-0.745^{a} \\
(-8.18)\end{array}$ & $\begin{array}{l}-0.119 \\
(-0.68)\end{array}$ & $\begin{array}{l}2.635^{a} \\
(19.60)\end{array}$ & $\begin{array}{c}0.966^{a} \\
(11.30)\end{array}$ & $\begin{array}{c}-0.745^{b} \\
(-2.07)\end{array}$ & $\begin{array}{l}-0.119 \\
(-0.20)\end{array}$ & $\begin{array}{l}2.635^{a} \\
(4.55)\end{array}$ & $\begin{array}{l}0.966^{b} \\
(2.14)\end{array}$ \\
\hline Cooperative central banl & & $\begin{array}{c}-0.377^{b} \\
-2.56)\end{array}$ & $\begin{array}{r}-1.157^{a} \\
-6.56)\end{array}$ & $\begin{array}{c}2.460^{a} \\
(9.17)\end{array}$ & $\begin{array}{c}0.763^{a} \\
(5.07)\end{array}$ & $\begin{array}{l}-0.377 \\
(-0.65)\end{array}$ & $\begin{array}{c}-1.157^{b} \\
(-2.38)\end{array}$ & $\begin{array}{l}2.460^{b} \\
(2.11)\end{array}$ & $\begin{array}{l}0.763 \\
(1.62)\end{array}$ \\
\hline Private loan banks & & $\begin{array}{l}0.080 \\
(0.78)\end{array}$ & $\begin{array}{l}0.045 \\
(0.29)\end{array}$ & $\begin{array}{l}1.070^{a} \\
(7.26)\end{array}$ & $\begin{array}{c}0.585^{a} \\
(7.11)\end{array}$ & $\begin{array}{l}0.080 \\
(0.22)\end{array}$ & $\begin{array}{l}0.045 \\
(0.09)\end{array}$ & $\begin{array}{l}1.070^{c} \\
(1.71)\end{array}$ & $\begin{array}{l}0.585 \\
(1.38)\end{array}$ \\
\hline Special purpose banks & & $\begin{array}{c}0.204 \\
(1.14)\end{array}$ & $\begin{array}{c}2.736^{a} \\
(6.61)\end{array}$ & $\begin{array}{l}4.856^{a} \\
(18.24)\end{array}$ & $\begin{array}{c}2.874^{a} \\
(16.91)\end{array}$ & $\begin{array}{l}0.204 \\
(0.42)\end{array}$ & $\begin{array}{l}2.736^{b} \\
(1.99)\end{array}$ & $\begin{array}{l}4.856^{a} \\
(4.03)\end{array}$ & $\begin{array}{c}2.874^{a} \\
(3.27)\end{array}$ \\
\hline Constant & & $\begin{array}{c}0.808^{a} \\
(4.05)\end{array}$ & $\begin{array}{l}0.750^{c} \\
(1.91)\end{array}$ & $\begin{array}{l}6.930^{a} \\
(20.92)\end{array}$ & $\begin{array}{l}4.216^{a} \\
(21.71)\end{array}$ & $\begin{array}{c}0.808 \\
(1.11)\end{array}$ & $\begin{array}{l}0.750 \\
(0.58)\end{array}$ & $\begin{array}{l}6.930^{a} \\
(4.86)\end{array}$ & $\begin{array}{l}4.216^{a} \\
(4.15)\end{array}$ \\
\hline \# maintenance periods & & 19 & 13 & 24 & 56 & 19 & 13 & 24 & 56 \\
\hline \# of observations & & 14,886 & 9,453 & 29,494 & 53,833 & 14,886 & 9,453 & 29,494 & 53,833 \\
\hline Adj. R-squared & & 0.0374 & 0.0507 & 0.2111 & 0.4965 & 0.0374 & 0.0507 & 0.2111 & 0.4965 \\
\hline
\end{tabular}


Table 6

Heckman selection regressions of haircut on size and financial health.

Each column represents a separate regression carried out on the population of bank-maintenance period observations. The first four columns show regressions for the "Pre-Crisis", the "Early Crisis", the "Full Allotment", and the total period with Huber-White corrected standard errors. Columns five to eight show the same regressions with standard errors clustered on banks. All regressions (main and selection) include maintenance period and banking group fixed effects. Base category for the banking groups is "Private banks". $z$-statistics are in brackets underneath the coefficients. $a, b$, and $c$ denote significance (two-tailed) at $1 \%, 5 \%$, and $10 \%$ level, respectively. For the period labelled "Total," note that observations in the period September 10 to November 11, 2008, are dropped.

In the main regressions, the dependent variable is haircut (in percent). For variables subscripted by $m-1$ and $y-1$, values are taken from end-of-month and end-of-year preceding each maintenance period, respectively. Ln(assets) measures bank size. Financial health is measured by equity ratio, write-offs \& provisions, and ROA. In the selection equation, we regress a dummy of whether a bank has positive liquidity uptake in maintenance period $j$ on a dummy of whether the bank had positive liquidity uptake in the preceding maintenance period, $j-1$, and all variables in the main equation.

\begin{tabular}{|c|c|c|c|c|c|c|c|c|c|}
\hline & & \multicolumn{4}{|c|}{ Heckman, Huber-White SEs } & \multicolumn{4}{|c|}{ Heckman, with clustering on banks } \\
\hline & & $\begin{array}{c}\text { Pre-Crisis } \\
18.01 .06- \\
07.08 .07\end{array}$ & $\begin{array}{c}\text { Early Crisis } \\
08.08 .07- \\
09.09 .08\end{array}$ & $\begin{array}{c}\text { Full Allot. } \\
12.11 .08- \\
09.11 .10\end{array}$ & $\begin{array}{c}\text { Total } \\
18.01 .06- \\
09.11 .10\end{array}$ & $\begin{array}{c}\text { Pre-Crisis } \\
18.01 .06- \\
07.08 .07\end{array}$ & $\begin{array}{c}\text { Early Crisis } \\
08.08 .07- \\
09.09 .08\end{array}$ & $\begin{array}{c}\text { Full Allot. } \\
12.11 .08- \\
09.11 .10\end{array}$ & $\begin{array}{c}\text { Total } \\
18.01 .06- \\
09.11 .10\end{array}$ \\
\hline \multicolumn{10}{|l|}{ Main equation: haircut } \\
\hline \multirow{2}{*}{$\ln (\text { assets })_{m-1}$} & $\ln ($ Eur $)$ & 0.008 & $0.107^{a}$ & $-0.184^{a}$ & $-0.098^{a}$ & 0.008 & 0.107 & $-0.184^{b}$ & -0.098 \\
\hline & & $(0.40)$ & $(3.01)$ & $(-9.37)$ & $(-6.88)$ & $(0.12)$ & $(0.95)$ & $(-2.28)$ & $(-1.37)$ \\
\hline \multirow{2}{*}{ 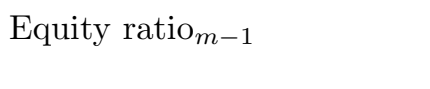 } & $\%$ & $-0.033^{a}$ & $-0.019^{a}$ & $-0.038^{a}$ & $-0.035^{a}$ & $-0.033^{b}$ & -0.019 & -0.038 & -0.035 \\
\hline & & $(-5.96)$ & $(-2.67)$ & $(-3.37)$ & $(-5.66)$ & $(-2.56)$ & $(-0.96)$ & $(-0.98)$ & $(-1.56)$ \\
\hline \multirow{2}{*}{ Write-offs \& $\operatorname{prov}_{y-1}$} & $\%$ & $0.313^{a}$ & 0.184 & $0.220^{a}$ & $0.188^{a}$ & $0.313^{c}$ & 0.184 & 0.220 & 0.188 \\
\hline & & $(4.30)$ & $(1.38)$ & $(4.87)$ & $(4.95)$ & $(1.66)$ & $(0.51)$ & $(1.55)$ & $(1.48)$ \\
\hline \multirow[t]{2}{*}{$\mathrm{ROA}_{y-1}$} & $\%$ & -0.030 & $-0.031^{b}$ & $0.049^{c}$ & $0.038^{c}$ & -0.030 & -0.031 & 0.049 & 0.038 \\
\hline & & $(-0.59)$ & $(-2.27)$ & $(1.88)$ & $(1.87)$ & $(-0.18)$ & $(-0.96)$ & $(1.03)$ & (1.14) \\
\hline \multirow[t]{2}{*}{ Savings banks } & & $-1.036^{a}$ & -0.240 & $-0.525^{a}$ & $-0.732^{a}$ & $-1.036^{b}$ & -0.240 & -0.525 & -0.732 \\
\hline & & $(-7.51)$ & $(-1.32)$ & $(-4.24)$ & $(-8.85)$ & $(-2.11)$ & $(-0.43)$ & $(-1.02)$ & $(-1.63)$ \\
\hline \multirow[t]{2}{*}{ Cooperatives } & & $-0.978^{a}$ & $-0.412^{a}$ & 0.186 & $-0.212^{a}$ & $-0.978^{c}$ & -0.412 & 0.186 & -0.212 \\
\hline & & $(-6.84)$ & $(-2.58)$ & $(1.62)$ & $(-2.69)$ & $(-1.95)$ & $(-0.86)$ & $(0.40)$ & $(-0.52)$ \\
\hline \multirow[t]{2}{*}{ Foreign banks } & & $-0.895^{a}$ & 0.650 & 0.167 & -0.070 & -0.895 & 0.650 & 0.167 & -0.070 \\
\hline & & $(-3.37)$ & $(0.98)$ & $(0.63)$ & $(-0.29)$ & $(-1.12)$ & $(0.34)$ & $(0.27)$ & $(-0.08)$ \\
\hline \multirow[t]{2}{*}{ Landesbanks } & & $-1.307^{a}$ & $-0.700^{a}$ & $2.216^{a}$ & $0.487^{a}$ & $-1.307^{b}$ & -0.700 & $2.216^{a}$ & 0.487 \\
\hline & & $(-8.88)$ & $(-2.80)$ & $(11.93)$ & $(4.03)$ & $(-2.41)$ & $(-0.84)$ & $(2.80)$ & $(0.71)$ \\
\hline \multirow[t]{2}{*}{ Cooperative central banks } & & $-1.512^{a}$ & $-1.928^{a}$ & $1.411^{a}$ & -0.142 & $-1.512^{a}$ & $-1.928^{b}$ & 1.411 & -0.142 \\
\hline & & $(-8.78)$ & $(-8.24)$ & $(4.25)$ & $(-0.77)$ & $(-2.80)$ & $(-2.47)$ & $(1.23)$ & $(-0.21)$ \\
\hline \multirow[t]{2}{*}{ Private loan banks } & & $-0.695^{a}$ & $-0.485^{b}$ & $0.508^{a}$ & -0.020 & -0.695 & -0.485 & 0.508 & -0.020 \\
\hline & & $(-4.18)$ & $(-2.20)$ & $(2.59)$ & $(-0.17)$ & $(-1.19)$ & $(-0.68)$ & $(0.61)$ & $(-0.03)$ \\
\hline \multirow[t]{2}{*}{ Special purpose banks } & & -0.041 & $2.251^{a}$ & $3.714^{a}$ & $2.290^{a}$ & -0.041 & 2.251 & $3.714^{a}$ & $2.290^{b}$ \\
\hline & & $(-0.17)$ & $(4.78)$ & $(11.10)$ & $(11.09)$ & $(-0.06)$ & $(1.55)$ & $(2.69)$ & $(2.32)$ \\
\hline \multirow[t]{2}{*}{ Constant } & & $3.189^{a}$ & 1.005 & $7.023^{a}$ & $4.939^{a}$ & $3.189^{b}$ & 1.005 & $7.023^{a}$ & $4.939^{a}$ \\
\hline & & $(-6.50)$ & $(-1.32)$ & $(-16.84)$ & $(-15.29)$ & $(2.04)$ & $(0.44)$ & $(4.45)$ & $(3.55)$ \\
\hline
\end{tabular}


Table 6 - continued

\begin{tabular}{|c|c|c|c|c|c|c|c|c|c|}
\hline & & \multicolumn{4}{|c|}{ Heckman, Huber-White SEs } & \multicolumn{4}{|c|}{ Heckman, with clustering on banks } \\
\hline & & $\begin{array}{c}\text { Pre-Crisis } \\
18.01 .06- \\
07.08 .07 \\
\end{array}$ & $\begin{array}{c}\text { Early Crisis } \\
08.08 .07- \\
09.09 .08 \\
\end{array}$ & $\begin{array}{c}\text { Full Allot. } \\
12.11 .08- \\
09.11 .10 \\
\end{array}$ & $\begin{array}{c}\text { Total } \\
18.01 .06- \\
09.11 .10 \\
\end{array}$ & $\begin{array}{c}\text { Pre-Crisis } \\
18.01 .06- \\
07.08 .07 \\
\end{array}$ & $\begin{array}{c}\text { Early Crisis } \\
08.08 .07- \\
09.09 .08 \\
\end{array}$ & $\begin{array}{c}\text { Full Allot. } \\
12.11 .08- \\
09.11 .10 \\
\end{array}$ & $\begin{array}{c}\text { Total } \\
18.01 .06- \\
09.11 .10 \\
\end{array}$ \\
\hline \multicolumn{10}{|c|}{ Selection equation: bank has positive liquidity uptake in maintenance period $j$} \\
\hline Positive liquidity uptake $_{j-1}$ & & $\begin{array}{l}2.829^{a} \\
(81.78)\end{array}$ & $\begin{array}{l}2.378^{a} \\
(61.12)\end{array}$ & $\begin{array}{l}2.988^{a} \\
(91.89)\end{array}$ & $\begin{array}{c}2.824^{a} \\
(139.85)\end{array}$ & $\begin{array}{l}2.829^{a} \\
(47.79)\end{array}$ & $\begin{array}{l}2.378^{a} \\
(42.20)\end{array}$ & $\begin{array}{l}2.988^{a} \\
(68.37)\end{array}$ & $\begin{array}{l}2.824^{a} \\
(81.79)\end{array}$ \\
\hline $\ln (\text { assets })_{m-1}$ & $\ln ($ Eur $)$ & $\begin{array}{c}0.125^{a} \\
(8.89)\end{array}$ & $\begin{array}{c}0.133^{a} \\
(8.17)\end{array}$ & $\begin{array}{c}0.037^{a} \\
(3.28)\end{array}$ & $\begin{array}{c}0.077^{a} \\
(9.92)\end{array}$ & $\begin{array}{c}0.125^{a} \\
(7.09)\end{array}$ & $\begin{array}{c}0.133^{a} \\
(7.39)\end{array}$ & $\begin{array}{l}0.037^{b} \\
(2.54)\end{array}$ & $\begin{array}{c}0.077^{a} \\
(6.77)\end{array}$ \\
\hline 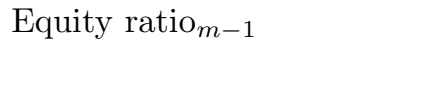 & $\%$ & $\begin{array}{l}-0.004 \\
(-0.83)\end{array}$ & $\begin{array}{l}0.001 \\
(0.16)\end{array}$ & $\begin{array}{l}-0.008 \\
(-1.31)\end{array}$ & $\begin{array}{l}-0.004 \\
(-1.10)\end{array}$ & $\begin{array}{l}-0.004 \\
(-0.52)\end{array}$ & $\begin{array}{l}0.001 \\
(0.21)\end{array}$ & $\begin{array}{l}-0.008 \\
(-1.16)\end{array}$ & $\begin{array}{l}-0.004 \\
(-0.74)\end{array}$ \\
\hline Write-offs \& $\operatorname{prov}_{y-1}$ & $\%$ & $\begin{array}{c}-0.115^{a} \\
(-2.87)\end{array}$ & $\begin{array}{c}-0.128^{b} \\
(-2.44)\end{array}$ & $\begin{array}{l}0.019 \\
(0.53)\end{array}$ & $\begin{array}{c}-0.056^{a} \\
(-2.65)\end{array}$ & $\begin{array}{c}-0.115^{b} \\
(-2.48)\end{array}$ & $\begin{array}{c}-0.128^{b} \\
(-2.42)\end{array}$ & $\begin{array}{l}0.019 \\
(0.48)\end{array}$ & $\begin{array}{c}-0.056^{b} \\
(-2.09)\end{array}$ \\
\hline $\mathrm{ROA}_{y-1}$ & $\%$ & $\begin{array}{l}-0.003 \\
(-0.24)\end{array}$ & $\begin{array}{l}-0.010 \\
(-0.67)\end{array}$ & $\begin{array}{l}-0.014 \\
(-1.35)\end{array}$ & $\begin{array}{l}-0.009 \\
(-1.18)\end{array}$ & $\begin{array}{l}-0.003 \\
(-0.26)\end{array}$ & $\begin{array}{l}-0.010 \\
(-1.00)\end{array}$ & $\begin{array}{l}-0.014 \\
(-1.10)\end{array}$ & $\begin{array}{l}-0.009 \\
(-1.12)\end{array}$ \\
\hline Savings banks & & $\begin{array}{l}0.069 \\
(1.23)\end{array}$ & $\begin{array}{c}-0.276^{a} \\
(-4.44)\end{array}$ & $\begin{array}{l}0.108^{b} \\
(2.04)\end{array}$ & $\begin{array}{l}0.017 \\
(0.51)\end{array}$ & $\begin{array}{l}0.069 \\
(0.91)\end{array}$ & $\begin{array}{c}-0.276^{a} \\
(-3.77)\end{array}$ & $\begin{array}{l}0.108 \\
(1.60)\end{array}$ & $\begin{array}{l}0.017 \\
(0.30)\end{array}$ \\
\hline Cooperatives & & $\begin{array}{l}0.290^{a} \\
(4.86)\end{array}$ & $\begin{array}{c}0.216^{a} \\
(3.41)\end{array}$ & $\begin{array}{c}0.289^{a} \\
(5.41)\end{array}$ & $\begin{array}{r}0.269^{a} \\
(7.87)\end{array}$ & $\begin{array}{l}0.290^{a} \\
(3.59)\end{array}$ & $\begin{array}{c}0.216^{a} \\
(2.80)\end{array}$ & $\begin{array}{c}0.289^{a} \\
(4.13)\end{array}$ & $\begin{array}{r}0.269^{a} \\
(4.57)\end{array}$ \\
\hline Foreign banks & & $\begin{array}{l}0.129 \\
(0.88)\end{array}$ & $\begin{array}{l}0.047 \\
(0.30)\end{array}$ & $\begin{array}{l}-0.177 \\
(-1.19)\end{array}$ & $\begin{array}{l}-0.029 \\
(-0.32)\end{array}$ & $\begin{array}{l}0.129 \\
(0.70)\end{array}$ & $\begin{array}{l}0.047 \\
(0.31)\end{array}$ & $\begin{array}{l}-0.177 \\
(-0.87)\end{array}$ & $\begin{array}{l}-0.029 \\
(-0.20)\end{array}$ \\
\hline Landesbanks & & $\begin{array}{l}0.645^{b} \\
(2.20)\end{array}$ & $\begin{array}{l}0.494^{c} \\
(1.85)\end{array}$ & $\begin{array}{c}0.313^{c} \\
(1.69)\end{array}$ & $\begin{array}{c}0.421^{a} \\
(3.44)\end{array}$ & $\begin{array}{l}0.645^{b} \\
(2.38)\end{array}$ & $\begin{array}{l}0.494^{c} \\
(1.95)\end{array}$ & $\begin{array}{l}0.313^{b} \\
(2.01)\end{array}$ & $\begin{array}{c}0.421^{a} \\
(2.97)\end{array}$ \\
\hline Cooperative central banks & & $\begin{array}{l}-0.218 \\
(-0.74)\end{array}$ & $\begin{array}{l}-0.035 \\
(-0.09)\end{array}$ & $\begin{array}{l}-0.077 \\
(-0.21)\end{array}$ & $\begin{array}{l}-0.056 \\
(-0.27)\end{array}$ & $\begin{array}{l}-0.218 \\
(-0.55)\end{array}$ & $\begin{array}{l}-0.035 \\
(-0.15)\end{array}$ & $\begin{array}{l}-0.077 \\
(-0.16)\end{array}$ & $\begin{array}{l}-0.056 \\
(-0.59)\end{array}$ \\
\hline Private loan banks & & $\begin{array}{l}0.119 \\
(0.81)\end{array}$ & $\begin{array}{c}0.607^{a} \\
(2.72)\end{array}$ & $\begin{array}{c}0.898^{a} \\
(4.31)\end{array}$ & $\begin{array}{c}0.509^{a} \\
(5.21)\end{array}$ & $\begin{array}{l}0.119 \\
(0.76)\end{array}$ & $\begin{array}{c}0.607^{a} \\
(3.72)\end{array}$ & $\begin{array}{c}0.898^{a} \\
(4.29)\end{array}$ & $\begin{array}{c}0.509^{a} \\
(3.80)\end{array}$ \\
\hline Special purpose banks & & $\begin{array}{l}0.027 \\
(0.18)\end{array}$ & $\begin{array}{l}-0.239 \\
(-1.52)\end{array}$ & $\begin{array}{l}-0.017 \\
(-0.13)\end{array}$ & $\begin{array}{l}-0.013 \\
(-0.15)\end{array}$ & $\begin{array}{l}0.027 \\
(0.17)\end{array}$ & $\begin{array}{l}-0.239 \\
(-1.39)\end{array}$ & $\begin{array}{l}-0.017 \\
(-0.09)\end{array}$ & $\begin{array}{l}-0.013 \\
(-0.10)\end{array}$ \\
\hline Constant & & $\begin{array}{l}-4.907^{a} \\
(-15.26) \\
\end{array}$ & $\begin{array}{l}-4.008^{a} \\
(-10.80) \\
\end{array}$ & $\begin{array}{c}-2.083^{a} \\
(-7.72) \\
\end{array}$ & $\begin{array}{l}-3.881^{a} \\
(-20.61) \\
\end{array}$ & $\begin{array}{l}-4.907^{a} \\
(-11.90) \\
\end{array}$ & $\begin{array}{c}-4.008^{a} \\
(-9.92) \\
\end{array}$ & $\begin{array}{c}-2.083^{a} \\
(-6.10) \\
\end{array}$ & $\begin{array}{l}-3.881^{a} \\
(-14.24) \\
\end{array}$ \\
\hline $\operatorname{atanh} \rho$ & & $\begin{array}{c}-0.064^{a} \\
(-3.19)\end{array}$ & $\begin{array}{c}-0.066^{b} \\
(-2.39)\end{array}$ & $\begin{array}{l}-0.031 \\
(-1.36)\end{array}$ & $\begin{array}{c}-0.055^{a} \\
(-3.87)\end{array}$ & $\begin{array}{c}-0.064^{a} \\
(-2.70)\end{array}$ & $\begin{array}{c}-0.066^{c} \\
(-1.92)\end{array}$ & $\begin{array}{l}-0.031 \\
(-0.98)\end{array}$ & $\begin{array}{c}-0.055^{a} \\
(-2.79)\end{array}$ \\
\hline $\ln (\sigma)$ & & $\begin{array}{c}0.348^{a} \\
(8.55)\end{array}$ & $\begin{array}{l}0.806^{a} \\
(21.70)\end{array}$ & $\begin{array}{l}0.700^{a} \\
(62.81)\end{array}$ & $\begin{array}{l}0.681^{a} \\
(63.53)\end{array}$ & $\begin{array}{c}0.348^{a} \\
(3.27)\end{array}$ & $\begin{array}{c}0.806^{a} \\
(7.01)\end{array}$ & $\begin{array}{c}0.700^{a} \\
(14.50)\end{array}$ & $\begin{array}{c}0.681^{a} \\
(12.30)\end{array}$ \\
\hline \# maintenance periods & & 18 & 13 & 23 & 54 & 18 & 13 & 23 & 54 \\
\hline \# of observations & & 14,038 & 9,453 & 28,393 & 51,884 & 14,038 & 9,453 & 28,393 & 51,884 \\
\hline$\lambda$ & & -0.0910 & -0.1478 & -0.0623 & -0.1081 & -0.0910 & -0.1478 & -0.0623 & -0.1081 \\
\hline$\sigma$ & & 1.4165 & 2.2385 & 2.0132 & 1.9751 & 1.4165 & 2.2385 & 2.0132 & 1.9751 \\
\hline$\rho$ & & -0.0643 & -0.0660 & -0.0309 & -0.0547 & -0.0643 & -0.0660 & -0.0309 & -0.0547 \\
\hline
\end{tabular}




\section{Table 7}

Decomposition of haircut - correlations between indicated variables and regressions of haircut on them.

The population is bank-maintenance period observations. Panel A shows correlations between indicated variables (haircut ingredients), which are duration, probability of default, and liquidity category of collateral. The correlations are shown for the "Pre-Crisis", the "Early Crisis", the "Full Allotment", and the total period. For the period labelled "Total," note that observations in the period September 10 to November 11, 2008, are dropped.

In Panel B, each column represents a separate panel regression of haircut (in percent) on indicated variables for the same sub-periods and the total period. Each regression includes maintenance period fixed effects. Standard errors are Huber-White corrected. $t$-statistics are in brackets underneath the coefficients. $a, b$, and $c$ denote significance (two-tailed) at $1 \%, 5 \%$, and $10 \%$ level, respectively.

Panel A: Correlations of indicated variables per sub period and the full period

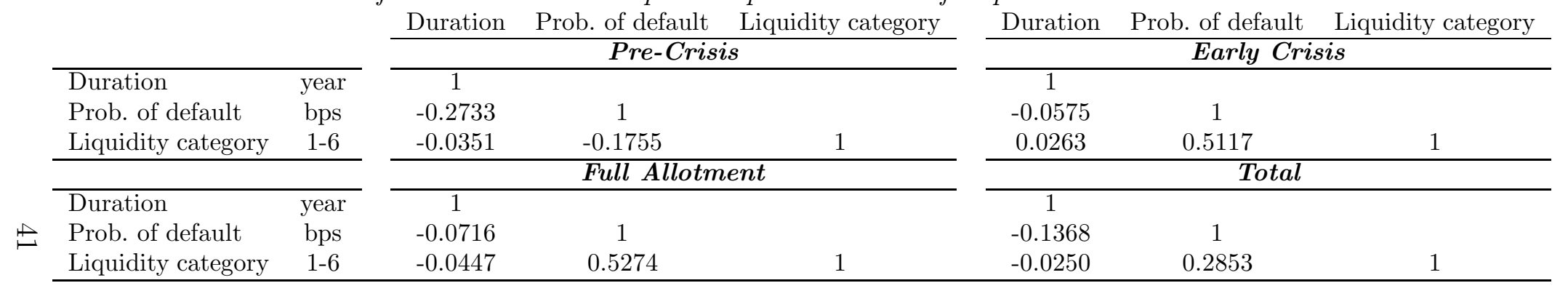

\begin{tabular}{|c|c|c|c|c|c|}
\hline \multicolumn{6}{|l|}{ Panel B: Panel } \\
\hline & & $\begin{array}{c}\text { Pre-Crisis } \\
18.01 .06- \\
07.08 .07\end{array}$ & $\begin{array}{c}\text { Early Crisis } \\
08.08 .07- \\
09.09 .08\end{array}$ & $\begin{array}{c}\text { Full Allotment } \\
12.11 .08- \\
09.11 .10\end{array}$ & $\begin{array}{c}\text { Total } \\
18.01 .06- \\
09.11 .10\end{array}$ \\
\hline Duration & year & $\begin{array}{c}0.293^{a} \\
(48.21)\end{array}$ & $\begin{array}{l}0.228^{a} \\
(15.72)\end{array}$ & $\begin{array}{l}0.256^{a} \\
(21.72)\end{array}$ & $\begin{array}{l}0.264^{a} \\
(34.96)\end{array}$ \\
\hline Prob. of default & bps & $\begin{array}{r}-0.003^{a} \\
(-3.54)\end{array}$ & $\begin{array}{c}0.052^{a} \\
(6.23)\end{array}$ & $\begin{array}{l}0.151^{a} \\
(33.36)\end{array}$ & $\begin{array}{l}0.034^{a} \\
(34.10)\end{array}$ \\
\hline Liquidity category & $1-6$ & $\begin{array}{c}0.628^{a} \\
(16.58)\end{array}$ & $\begin{array}{l}1.001^{a} \\
(18.18)\end{array}$ & $\begin{array}{c}2.397^{a} \\
(114.45)\end{array}$ & $\begin{array}{l}1.812^{a} \\
(99.88)\end{array}$ \\
\hline Constant & & $\begin{array}{l}-0.172^{c} \\
(-1.65)\end{array}$ & $\begin{array}{c}-0.964^{a} \\
(-6.21)\end{array}$ & $\begin{array}{l}-3.458^{a} \\
(-44.66)\end{array}$ & $\begin{array}{l}-2.155^{a} \\
(-34.79)\end{array}$ \\
\hline \# of maintenance & eriods & 19 & 13 & 24 & 56 \\
\hline \# of observations & & 14,886 & 9,453 & 29,494 & 53,833 \\
\hline Adj. R-squared & & 0.3204 & 0.2355 & 0.6727 & 0.6963 \\
\hline
\end{tabular}


Table 8

Tobit panel regressions of normalized credit on size, collateral quality, and financial health.

Each column represents a separate regression carried out on the population of bank-maintenance period observations. Each of them includes maintenance period and banking group fixed effects. Base category for the banking groups is "Private banks". The first four columns show regressions for the "Pre-Crisis", the "Early Crisis", the "Full Allotment", and the total period with Huber-White corrected standard errors. Columns five to eight show the equivalent regressions but with standard errors clustered on the bank level. $t$-statistics are in brackets underneath the coefficients. $a, b$, and $c$ denote significance (two-tailed) at $1 \%, 5 \%$, and $10 \%$ level, respectively. For the period labelled "Total," note that observations in the period September 10 to November 11, 2008, are dropped.

The dependent variable is normalized credit (in percent; normalized by total assets taken from end-of-month preceding each maintenance period). For variables subscripted by $m-1$ and $y-1$, values are taken from end-of-month and end-of-year preceding each maintenance period, respectively. Ln(assets) measures bank size. Haircut measures collateral quality. Financial health is measured by equity ratio, write-offs \& provisions, and ROA.

\begin{tabular}{|c|c|c|c|c|c|c|c|c|c|}
\hline & \multicolumn{4}{|c|}{ Tobit panel, Huber-White SEs } & \multicolumn{4}{|c|}{ Tobit panel, with clustering on banks } \\
\hline & & $\begin{array}{c}\text { Pre-Crisis } \\
18.01 .06- \\
07.08 .07\end{array}$ & $\begin{array}{c}\text { Early Crisis } \\
08.08 .07- \\
09.09 .08\end{array}$ & $\begin{array}{c}\text { Full Allot. } \\
12.11 .08- \\
09.11 .10\end{array}$ & $\begin{array}{c}\text { Total } \\
18.01 .06- \\
09.11 .10\end{array}$ & $\begin{array}{c}\text { Pre-Crisis } \\
18.01 .06- \\
07.08 .07\end{array}$ & $\begin{array}{c}\text { Early Crisis } \\
08.08 .07- \\
09.09 .08\end{array}$ & $\begin{array}{c}\text { Full Allot. } \\
12.11 .08- \\
09.11 .10\end{array}$ & $\begin{array}{c}\text { Total } \\
18.01 .06- \\
09.11 .10\end{array}$ \\
\hline $\ln (\text { assets })_{m-1}$ & $\ln$ (Eur) & $\begin{array}{l}1.450^{a} \\
(17.57)\end{array}$ & $\begin{array}{l}1.199^{a} \\
(15.65)\end{array}$ & $\begin{array}{l}0.140^{a} \\
(5.11)\end{array}$ & $\begin{array}{l}0.584^{a} \\
(21.80)\end{array}$ & $\begin{array}{l}1.450^{a} \\
(4.50)\end{array}$ & $\begin{array}{l}1.199^{a} \\
(5.73)\end{array}$ & $\begin{array}{c}0.140 \\
(1.33)\end{array}$ & $\begin{array}{l}0.584^{a} \\
(4.65)\end{array}$ \\
\hline Haircut & $\%$ & $\begin{array}{c}0.813^{a} \\
(15.41)\end{array}$ & $\begin{array}{c}0.378^{a} \\
(10.28)\end{array}$ & $\begin{array}{c}0.149^{a} \\
(10.84)\end{array}$ & $\begin{array}{l}0.268^{a} \\
(20.83)\end{array}$ & $\begin{array}{c}0.813^{a} \\
(5.00)\end{array}$ & $\begin{array}{c}0.378^{a} \\
(3.63)\end{array}$ & $\begin{array}{r}0.149^{a} \\
(2.90)\end{array}$ & $\begin{array}{l}0.268^{a} \\
(5.35)\end{array}$ \\
\hline 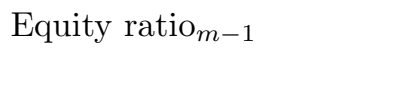 & $\%$ & $\begin{array}{l}-0.624^{a} \\
(-7.08)\end{array}$ & $\begin{array}{l}-0.309^{a} \\
(-4.50)\end{array}$ & $\begin{array}{l}-0.396^{a} \\
(-13.94)\end{array}$ & $\begin{array}{l}-0.428^{a} \\
(-15.27)\end{array}$ & $\begin{array}{c}-0.624^{c} \\
(-1.86)\end{array}$ & $\begin{array}{l}-0.309 \\
(-1.52)\end{array}$ & $\begin{array}{c}-0.396^{a} \\
(-3.65)\end{array}$ & $\begin{array}{c}-0.428^{a} \\
(-3.04)\end{array}$ \\
\hline Equity ratio ${ }_{m-1}^{2}$ & $\%^{2}$ & $\begin{array}{l}0.008^{a} \\
(7.37)\end{array}$ & $\begin{array}{c}0.006^{a} \\
(5.26)\end{array}$ & $\begin{array}{c}0.006^{a} \\
(9.62)\end{array}$ & $\begin{array}{c}0.006^{a} \\
(13.99)\end{array}$ & $\begin{array}{l}0.008^{c} \\
(1.93)\end{array}$ & $\begin{array}{l}0.006^{b} \\
(2.45)\end{array}$ & $\begin{array}{l}0.006^{a} \\
(2.95)\end{array}$ & $\begin{array}{c}0.006^{a} \\
(3.33)\end{array}$ \\
\hline Write-offs \& $\operatorname{prov}_{y-1}$ & $\%$ & $\begin{array}{l}-1.507^{a} \\
(-2.62)\end{array}$ & $\begin{array}{l}-1.351^{a} \\
(-5.76)\end{array}$ & $\begin{array}{c}0.920^{a} \\
(9.53)\end{array}$ & $\begin{array}{l}-0.205^{a} \\
(-3.01)\end{array}$ & $\begin{array}{l}-1.507^{b} \\
(-1.96)\end{array}$ & $\begin{array}{l}-1.351^{b} \\
(-2.30)\end{array}$ & $\begin{array}{r}0.920^{a} \\
(2.66)\end{array}$ & $\begin{array}{l}-0.205 \\
(-0.87)\end{array}$ \\
\hline $\mathrm{ROA}_{y-1}$ & $\%$ & $\begin{array}{l}0.021 \\
(0.37)\end{array}$ & $\begin{array}{l}0.071 \\
(1.27)\end{array}$ & $\begin{array}{l}0.007 \\
(0.19)\end{array}$ & $\begin{array}{l}0.026 \\
(1.04)\end{array}$ & $\begin{array}{l}0.021 \\
(0.12)\end{array}$ & $\begin{array}{l}0.071 \\
(0.65)\end{array}$ & $\begin{array}{l}0.007 \\
(0.06)\end{array}$ & $\begin{array}{l}0.026 \\
(0.31)\end{array}$ \\
\hline Deposit flow banks & $\%$ & $\begin{array}{l}0.154^{a} \\
(2.58)\end{array}$ & $\begin{array}{l}0.164^{b} \\
(2.33)\end{array}$ & $\begin{array}{l}-0.008 \\
(-0.80)\end{array}$ & $\begin{array}{l}0.020 \\
(1.42)\end{array}$ & $\begin{array}{l}0.154^{c} \\
(1.75)\end{array}$ & $\begin{array}{l}0.164^{b} \\
(1.96)\end{array}$ & $\begin{array}{l}-0.008 \\
(-0.68)\end{array}$ & $\begin{array}{l}0.020 \\
(1.16)\end{array}$ \\
\hline Deposit flow non-banks & $\%$ & $\begin{array}{l}-0.080^{c} \\
(-1.74)\end{array}$ & $\begin{array}{l}-0.121^{b} \\
(-2.55)\end{array}$ & $\begin{array}{l}0.016 \\
(1.15)\end{array}$ & $\begin{array}{l}-0.008 \\
(-0.61)\end{array}$ & $\begin{array}{l}-0.080 \\
(-1.55)\end{array}$ & $\begin{array}{l}-0.121^{a} \\
(-2.59)\end{array}$ & $\begin{array}{l}0.016 \\
(0.90)\end{array}$ & $\begin{array}{l}-0.008 \\
(-0.53)\end{array}$ \\
\hline Savings banks & & $\begin{array}{l}-0.966^{b} \\
-2.58)\end{array}$ & $\begin{array}{l}-3.906^{a} \\
(-10.43)\end{array}$ & $\begin{array}{c}-0.611^{a} \\
(-3.60)\end{array}$ & $\begin{array}{l}-1.553^{a} \\
(-10.20)\end{array}$ & $\begin{array}{l}-0.966 \\
(-0.66)\end{array}$ & $\begin{array}{l}-3.906^{a} \\
(-3.52)\end{array}$ & $\begin{array}{l}-0.611 \\
-0.88)\end{array}$ & $\begin{array}{l}-1.553^{c} \\
(-1.89)\end{array}$ \\
\hline Cooperatives & & $\begin{array}{l}1.270^{a} \\
(3.57)\end{array}$ & $\begin{array}{l}0.493 \\
(1.50)\end{array}$ & $\begin{array}{l}1.174^{a} \\
(6.62)\end{array}$ & $\begin{array}{l}0.652^{a} \\
(4.52)\end{array}$ & $\begin{array}{l}1.270 \\
(0.94)\end{array}$ & $\begin{array}{l}0.493 \\
(0.48)\end{array}$ & $\begin{array}{l}1.174 \\
(1.62)\end{array}$ & $\begin{array}{l}0.652 \\
(0.81)\end{array}$ \\
\hline Foreign banks & & $\begin{array}{l}4.625^{a} \\
(3.94)\end{array}$ & $\begin{array}{l}1.859^{c} \\
(1.87)\end{array}$ & $\begin{array}{r}-2.161^{a} \\
(-4.81)\end{array}$ & $\begin{array}{c}0.702 \\
(1.36)\end{array}$ & $\begin{array}{l}4.625 \\
(0.95)\end{array}$ & $\begin{array}{l}1.859 \\
(0.57)\end{array}$ & $\begin{array}{l}-2.161 \\
(-1.22)\end{array}$ & $\begin{array}{l}0.702 \\
(0.24)\end{array}$ \\
\hline Landesbanks & & $\begin{array}{l}-1.733^{a} \\
(-3.19)\end{array}$ & $\begin{array}{l}-1.402^{b} \\
(-2.36)\end{array}$ & $\begin{array}{l}0.297 \\
(0.89)\end{array}$ & $\begin{array}{l}-0.275 \\
(-1.04)\end{array}$ & $\begin{array}{l}-1.733 \\
(-0.82)\end{array}$ & $\begin{array}{l}-1.402 \\
(-0.79)\end{array}$ & $\begin{array}{l}0.297 \\
(0.21)\end{array}$ & $\begin{array}{l}-0.275 \\
(-0.21)\end{array}$ \\
\hline Cooperative central banks & & $\begin{array}{c}-4.180^{a} \\
(-3.58)\end{array}$ & $\begin{array}{l}-3.503^{a} \\
(-3.51)\end{array}$ & $\begin{array}{c}-2.847^{a} \\
(-4.70)\end{array}$ & $\begin{array}{l}-2.812^{a} \\
(-4.75)\end{array}$ & $\begin{array}{l}-4.180 \\
(-0.86)\end{array}$ & $\begin{array}{l}-3.503 \\
(-1.24)\end{array}$ & $\begin{array}{l}-2.847 \\
(-1.28)\end{array}$ & $\begin{array}{l}-2.812^{c} \\
(-1.89)\end{array}$ \\
\hline Private loan banks & & $\begin{array}{c}-5.064^{a} \\
(-7.90)\end{array}$ & $\begin{array}{l}-1.003^{b} \\
(-1.97)\end{array}$ & $\begin{array}{l}5.286^{a} \\
(10.25)\end{array}$ & $\begin{array}{l}1.046^{a} \\
(3.23)\end{array}$ & $\begin{array}{l}-5.064^{b} \\
(-2.06)\end{array}$ & $\begin{array}{l}-1.003 \\
(-0.71)\end{array}$ & $\begin{array}{l}5.286^{b} \\
(2.32)\end{array}$ & $\begin{array}{l}1.046 \\
(0.68)\end{array}$ \\
\hline Special purpose banks & & $\begin{array}{r}-2.286^{a} \\
(-3.65) \\
\end{array}$ & $\begin{array}{r}-4.001^{a} \\
(-6.21) \\
\end{array}$ & $\begin{array}{r}-1.901^{a} \\
(-6.06) \\
\end{array}$ & $\begin{array}{r}-2.140^{a} \\
(-7.22) \\
\end{array}$ & $\begin{array}{r}-2.286 \\
(-0.95) \\
\end{array}$ & $\begin{array}{c}-4.001^{b} \\
(-2.15) \\
\end{array}$ & $\begin{array}{l}-1.901 \\
(-1.54) \\
\end{array}$ & $\begin{array}{l}-2.140 \\
(-1.55)\end{array}$ \\
\hline
\end{tabular}


Table 8 - continued

\begin{tabular}{|c|c|c|c|c|c|c|c|c|}
\hline & \multicolumn{4}{|c|}{ Tobit panel, Huber-White SEs } & \multicolumn{4}{|c|}{ Tobit panel, with clustering on banks } \\
\hline & Pre-Crisis & Early Crisis & Full Allot. & Total & Pre-Crisis & Early Crisis & Full Allot. & Total \\
\hline \multirow[t]{2}{*}{ Constant } & $-31.009^{a}$ & $-25.255^{a}$ & 0.107 & $-11.644^{a}$ & $-31.009^{a}$ & $-25.255^{a}$ & 0.107 & $-11.644^{a}$ \\
\hline & $(-16.87)$ & $(-14.53)$ & $(0.16)$ & $(-17.86)$ & $(-4.46)$ & $(-5.05)$ & $(0.04)$ & $(-3.90)$ \\
\hline \multirow[t]{2}{*}{ Sigma constant } & $7.029^{a}$ & $6.218^{a}$ & $4.555^{a}$ & $5.347^{a}$ & $7.029^{a}$ & $6.218^{a}$ & $4.555^{a}$ & $5.347^{a}$ \\
\hline & $(34.29)$ & $(33.78)$ & $(100.65)$ & $(83.29)$ & $(8.98)$ & $(14.00)$ & $(27.67)$ & $(18.58)$ \\
\hline \# of maintenance periods & 19 & 13 & 24 & 56 & 19 & 13 & 24 & 56 \\
\hline \# of observations & 14,886 & 9,453 & 29,494 & 53,833 & 14,886 & 9,453 & 29,494 & 53,833 \\
\hline Pseudo R-squred & 0.0364 & 0.0492 & 0.0391 & 0.0472 & 0.0364 & 0.0492 & 0.0391 & 0.0472 \\
\hline
\end{tabular}


Table 9

Tobit panel regressions of normalized credit on size, haircut decomposing collateral quality measures, financial health and deposit flow measures.

Each column represents a separate regression carried out on the population of bank-maintenance period observations. Each of them includes maintenance period and banking group fixed effects. Base category for the banking groups is "Private banks". The first four columns show regressions for the "Pre-Crisis", the "Early Crisis", the "Full Allotment", and the total period with Huber-White corrected standard errors. Columns five to eight show the equivalent regressions but with standard errors clustered on the bank level. $t$-statistics are in brackets underneath the coefficients. $a, b$, and $c$ denote significance (two-tailed) at $1 \%, 5 \%$, and $10 \%$ level, respectively. Panel A shows results for all eight banking groups. In Panel B private loan and special purpose banks are dropped from the sample. For the period labelled "Total," note that observations in the period September 10 to November 11, 2008, are dropped.

The dependent variable is normalized credit (in percent; normalized by total assets taken from end-of-month preceding each maintenance period). For variables subscripted by $m-1$ and $y-1$, values are taken from end-of-month and end-of-year preceding each maintenance period, respectively. Ln(assets) measures bank size. Collateral quality is measured by the haircut composition measures (liquidity category, probability of default, and duration), the residual of an OLS regression of haircut on the haircut composition measures (per maintenance period), and the fraction of own use collateral. Financial health is measured by equity ratio, write-offs \& provisions, and ROA. Deposit flows are contemporaneous, normalized in the same manner as credit is normalized, and separated into flows of banks and flows of non-banks.

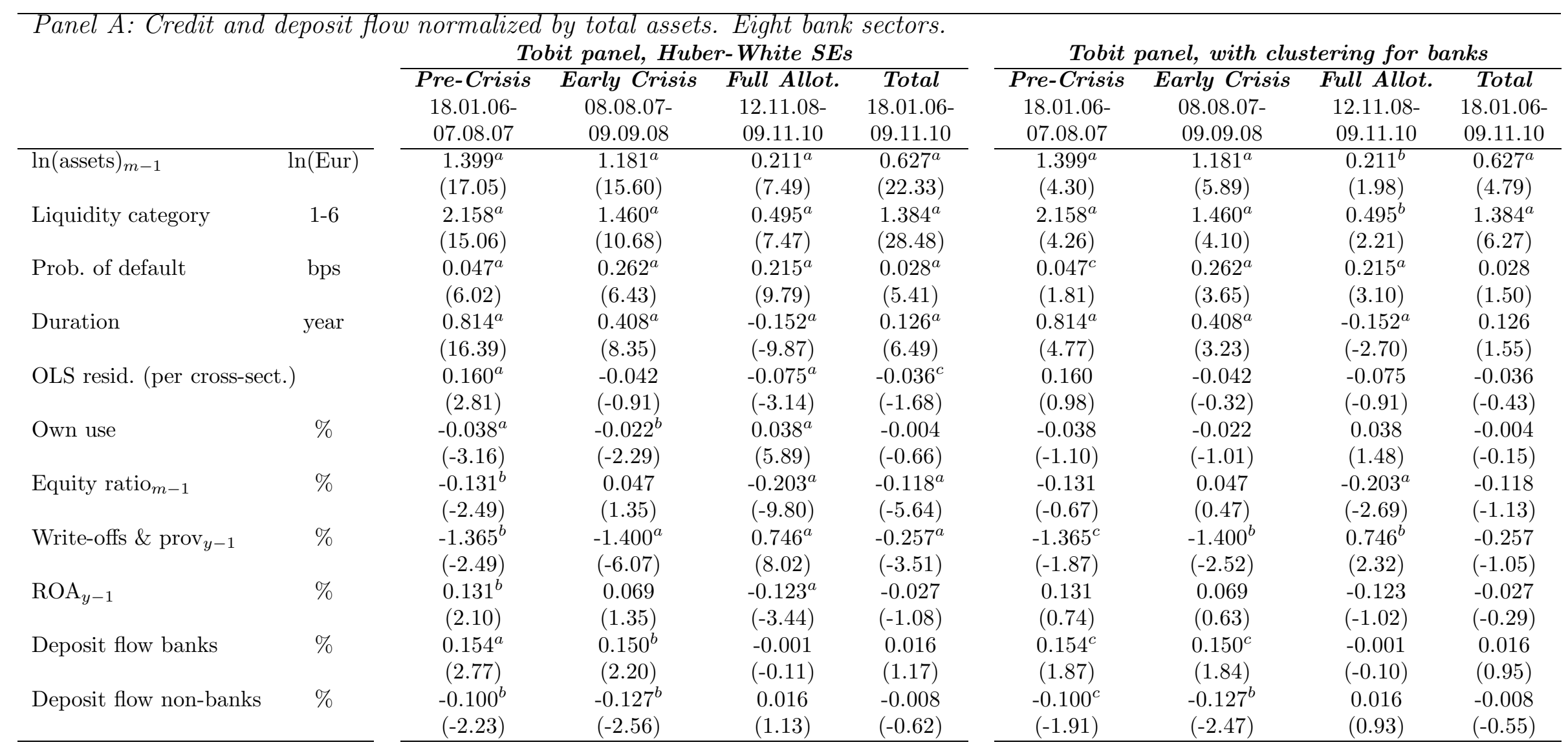


Table 9, Panel A - continued

\begin{tabular}{|c|c|c|c|c|c|c|c|c|}
\hline & \multicolumn{4}{|c|}{ Tobit panel, Huber-White SEs } & \multicolumn{4}{|c|}{ Tobit panel, with clustering for banks } \\
\hline & Pre-Crisis & Early Crisis & Full Allot. & Total & Pre-Crisis & Early Crisis & Full Allot. & Total \\
\hline \multirow[t]{2}{*}{ Savings banks } & $-0.671^{c}$ & $-3.298^{a}$ & $-0.396^{b}$ & $-1.485^{a}$ & -0.671 & $-3.298^{a}$ & -0.396 & $-1.485^{c}$ \\
\hline & $(-1.88)$ & $(-9.47)$ & $(-2.30)$ & $(-9.86)$ & $(-0.48)$ & $(-3.25)$ & $(-0.57)$ & $(-1.81)$ \\
\hline \multirow[t]{2}{*}{ Cooperatives } & $1.202^{a}$ & 0.314 & $1.219^{a}$ & $0.480^{a}$ & 1.202 & 0.314 & $1.219^{c}$ & 0.480 \\
\hline & $(3.53)$ & $(0.98)$ & $(6.79)$ & $(3.31)$ & $(0.92)$ & $(0.31)$ & $(1.67)$ & $(0.59)$ \\
\hline \multirow[t]{2}{*}{ Foreign banks } & $4.592^{a}$ & $1.623^{c}$ & $-2.251^{a}$ & 0.592 & 4.592 & 1.623 & -2.251 & 0.592 \\
\hline & $(4.23)$ & $(1.66)$ & $(-5.46)$ & (1.19) & $(1.03)$ & $(0.52)$ & $(-1.47)$ & $(0.21)$ \\
\hline \multirow[t]{2}{*}{ Landesbanks } & $-2.293^{a}$ & $-2.435^{a}$ & -0.132 & $-0.843^{a}$ & -2.293 & -2.435 & -0.132 & -0.843 \\
\hline & $(-4.24)$ & $(-4.23)$ & $(-0.39)$ & $(-3.18)$ & $(-1.09)$ & $(-1.46)$ & $(-0.09)$ & $(-0.64)$ \\
\hline \multirow[t]{2}{*}{ Cooperative central banks } & $-6.768^{a}$ & $-5.819^{a}$ & $-2.445^{a}$ & $-3.619^{a}$ & -6.768 & $-5.819^{a}$ & -2.445 & $-3.619^{a}$ \\
\hline & $(-6.28)$ & $(-6.38)$ & $(-3.95)$ & $(-6.11)$ & $(-1.55)$ & $(-2.77)$ & $(-1.07)$ & $(-2.94)$ \\
\hline \multirow[t]{2}{*}{ Private loan banks } & $-5.913^{a}$ & $-1.553^{a}$ & $4.074^{a}$ & $0.945^{a}$ & $-5.913^{b}$ & -1.553 & $4.074^{b}$ & 0.945 \\
\hline & $(-8.89)$ & $(-2.94)$ & $(8.45)$ & $(3.06)$ & $(-2.36)$ & $(-1.09)$ & $(2.00)$ & $(0.64)$ \\
\hline \multirow[t]{2}{*}{ Special purpose banks } & $-3.847^{a}$ & $-4.350^{a}$ & $-1.519^{a}$ & $-2.360^{a}$ & -3.847 & $-4.350^{b}$ & -1.519 & $-2.360^{c}$ \\
\hline & $(-5.90)$ & $(-6.74)$ & $(-4.85)$ & $(-8.09)$ & $(-1.50)$ & $(-2.32)$ & $(-1.28)$ & $(-1.71)$ \\
\hline \multirow[t]{2}{*}{ Constant } & $-38.775^{a}$ & $-31.866^{a}$ & $-3.722^{a}$ & $-17.466^{a}$ & $-38.775^{a}$ & $-31.866^{a}$ & -3.722 & $-17.466^{a}$ \\
\hline & $(-19.79)$ & $(-18.48)$ & $(-5.27)$ & $(-24.87)$ & $(-5.18)$ & $(-6.96)$ & $(-1.43)$ & $(-5.70)$ \\
\hline \multirow[t]{2}{*}{ Sigma constant } & $6.916^{a}$ & $6.067^{a}$ & $4.508^{a}$ & $5.332^{a}$ & $6.916^{a}$ & $6.067^{a}$ & $4.508^{a}$ & $5.332^{a}$ \\
\hline & $(34.92)$ & $(34.25)$ & $(102.45)$ & $(83.33)$ & $(9.05)$ & $(14.66)$ & $(28.44)$ & $(18.75)$ \\
\hline \# of maintenance periods & 19 & 13 & 24 & 56 & 19 & 13 & 24 & 56 \\
\hline \# of observations & 14,886 & 9,453 & 29,494 & 53,833 & 14,886 & 9,453 & 29,494 & 53,833 \\
\hline Pseudo R-squared & 0.0440 & 0.0589 & 0.0431 & 0.0489 & 0.0440 & 0.0589 & 0.0431 & 0.0489 \\
\hline
\end{tabular}


Table 9 - continued

Panel B: Credit and deposit flow normalized by total assets. Six bank sectors.

\begin{tabular}{|c|c|c|c|c|c|c|c|c|c|}
\hline & \multicolumn{4}{|c|}{ Tobit panel, Huber-White SEs } & \multicolumn{4}{|c|}{ Tobit panel, with clustering for banks } \\
\hline & & Pre-Crisis & Early Crisis & Full Allot. & Total & Pre-Crisis & Early Crisis & Full Allot. & Total \\
\hline \multirow[t]{2}{*}{$\ln (\text { assets })_{m-1}$} & $n($ Eur $)$ & $1.454^{a}$ & $1.221^{a}$ & $0.236^{a}$ & $0.650^{a}$ & $1.454^{a}$ & $1.221^{a}$ & $0.236^{b}$ & $0.650^{a}$ \\
\hline & & $(16.92)$ & $(15.51)$ & $(8.34)$ & $(22.90)$ & $(4.26)$ & $(5.87)$ & $(2.21)$ & $(4.93)$ \\
\hline \multirow[t]{2}{*}{ Liquidity category } & $1-6$ & $2.161^{a}$ & $1.521^{a}$ & $0.661^{a}$ & $1.494^{a}$ & $2.161^{a}$ & $1.521^{a}$ & $0.661^{a}$ & $1.494^{a}$ \\
\hline & & $(14.51)$ & $(10.71)$ & $(10.12)$ & $(30.16)$ & $(4.09)$ & $(4.09)$ & $(2.98)$ & $(6.57)$ \\
\hline \multirow[t]{2}{*}{ Prob. of default } & bps & $0.048^{a}$ & $0.263^{a}$ & $0.193^{a}$ & $0.025^{a}$ & $0.048^{c}$ & $0.263^{a}$ & $0.193^{a}$ & 0.025 \\
\hline & & $(6.00)$ & $(6.37)$ & $(9.03)$ & $(4.94)$ & $(1.80)$ & $(3.60)$ & $(2.85)$ & $(1.37)$ \\
\hline \multirow[t]{2}{*}{ Duration } & year & $0.830^{a}$ & $0.408^{a}$ & $-0.133^{a}$ & $0.139^{a}$ & $0.830^{a}$ & $0.408^{a}$ & $-0.133^{b}$ & $0.139^{c}$ \\
\hline & & $(15.85)$ & $(8.02)$ & $(-8.96)$ & $(7.01)$ & $(4.61)$ & $(3.10)$ & $(-2.48)$ & $(1.69)$ \\
\hline \multirow{2}{*}{\multicolumn{2}{|c|}{ OLS resid. (per cross-sect.) }} & $0.188^{a}$ & -0.053 & $-0.061^{b}$ & -0.012 & 0.188 & -0.053 & -0.061 & -0.012 \\
\hline & & $(3.15)$ & $(-1.06)$ & $(-2.56)$ & $(-0.55)$ & $(1.06)$ & $(-0.38)$ & $(-0.74)$ & $(-0.14)$ \\
\hline \multirow[t]{2}{*}{ Own use } & $\%$ & $-0.294^{a}$ & $-0.083^{a}$ & -0.007 & $-0.072^{a}$ & $-0.294^{c}$ & $-0.083^{b}$ & -0.007 & $-0.072^{a}$ \\
\hline & & $(-5.92)$ & $(-4.14)$ & $(-1.04)$ & $(-9.85)$ & $(-1.70)$ & $(-2.28)$ & $(-0.36)$ & $(-3.08)$ \\
\hline \multirow{2}{*}{ 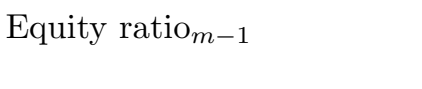 } & $\%$ & $-0.117^{b}$ & 0.055 & $-0.200^{a}$ & $-0.110^{a}$ & -0.117 & 0.055 & $-0.200^{a}$ & -0.110 \\
\hline & & $(-2.29)$ & $(1.54)$ & $(-9.40)$ & $(-5.32)$ & $(-0.62)$ & $(0.54)$ & $(-2.59)$ & $(-1.06)$ \\
\hline \multirow{2}{*}{ Write-offs \& $\operatorname{prov}_{y-1}$} & $\%$ & $-1.354^{b}$ & $-1.359^{a}$ & $0.703^{a}$ & $-0.286^{a}$ & $-1.354^{c}$ & $-1.359^{b}$ & $0.703^{b}$ & -0.286 \\
\hline & & $(-2.45)$ & $(-5.67)$ & $(7.41)$ & $(-3.75)$ & $(-1.83)$ & $(-2.37)$ & $(2.15)$ & $(-1.14)$ \\
\hline \multirow[t]{2}{*}{$\mathrm{ROA}_{y-1}$} & $\%$ & $0.136^{b}$ & 0.072 & $-0.089^{b}$ & 0.010 & 0.136 & 0.072 & -0.089 & 0.010 \\
\hline & & $(2.19)$ & (1.38) & $(-2.50)$ & $(0.38)$ & $(0.76)$ & $(0.64)$ & $(-0.75)$ & $(0.11)$ \\
\hline \multirow[t]{2}{*}{ Deposit flow banks } & $\%$ & $0.154^{a}$ & $0.153^{b}$ & -0.002 & 0.015 & $0.154^{c}$ & $0.153^{c}$ & -0.002 & 0.015 \\
\hline & & $(2.71)$ & $(2.20)$ & $(-0.21)$ & (1.05) & (1.83) & $(1.85)$ & $(-0.19)$ & $(0.86)$ \\
\hline \multirow[t]{2}{*}{ Deposit flow non-banks } & $\%$ & $-0.100^{b}$ & $-0.128^{b}$ & 0.015 & -0.008 & $-0.100^{c}$ & $-0.128^{b}$ & 0.015 & -0.008 \\
\hline & & $(-2.19)$ & $(-2.52)$ & $(1.06)$ & $(-0.61)$ & $(-1.86)$ & $(-2.43)$ & $(0.87)$ & $(-0.54)$ \\
\hline \multirow[t]{2}{*}{ Savings banks } & & $-0.723^{b}$ & $-3.366^{a}$ & $-0.660^{a}$ & $-1.670^{a}$ & -0.723 & $-3.366^{a}$ & -0.660 & $-1.670^{b}$ \\
\hline & & $(-1.97)$ & $(-9.45)$ & $(-3.84)$ & $(-11.01)$ & $(-0.50)$ & $(-3.25)$ & $(-0.95)$ & $(-2.03)$ \\
\hline \multirow[t]{2}{*}{ Cooperatives } & & $1.211^{a}$ & 0.314 & $0.942^{a}$ & $0.287^{b}$ & 1.211 & 0.314 & 0.942 & 0.287 \\
\hline & & $(3.46)$ & $(0.96)$ & $(5.27)$ & (1.97) & $(0.90)$ & $(0.31)$ & $(1.30)$ & $(0.35)$ \\
\hline \multirow[t]{2}{*}{ Foreign banks } & & $4.585^{a}$ & 1.614 & $-2.472^{a}$ & 0.402 & 4.585 & 1.614 & -2.472 & 0.402 \\
\hline & & $(4.19)$ & (1.64) & $(-6.05)$ & $(0.81)$ & $(1.02)$ & $(0.51)$ & $(-1.63)$ & $(0.14)$ \\
\hline \multirow[t]{2}{*}{ Landesbanks } & & $-2.066^{a}$ & $-2.467^{a}$ & -0.232 & $-0.923^{a}$ & -2.066 & -2.467 & -0.232 & -0.923 \\
\hline & & $(-3.87)$ & $(-4.25)$ & $(-0.69)$ & $(-3.51)$ & $(-1.01)$ & $(-1.48)$ & $(-0.17)$ & $(-0.71)$ \\
\hline \multirow{2}{*}{\multicolumn{2}{|c|}{ Cooperative central banks }} & $-6.327^{a}$ & $-5.937^{a}$ & $-2.872^{a}$ & $-3.904^{a}$ & -6.327 & $-5.937^{a}$ & -2.872 & $-3.904^{a}$ \\
\hline & & $(-6.34)$ & $(-6.42)$ & $(-4.56)$ & $(-6.60)$ & $(-1.61)$ & $(-2.83)$ & $(-1.21)$ & $(-3.24)$ \\
\hline \multirow{2}{*}{\multicolumn{2}{|c|}{ Constant }} & $-40.112^{a}$ & $-33.020^{a}$ & $-4.464^{a}$ & $-18.032^{a}$ & $-40.112^{a}$ & $-33.020^{a}$ & $-4.464^{c}$ & $-18.032^{a}$ \\
\hline & & $(-19.66)$ & $(-18.40)$ & $(-6.32)$ & $(-25.43)$ & $(-5.13)$ & $(-6.96)$ & $(-1.71)$ & $(-5.85)$ \\
\hline \multirow{2}{*}{\multicolumn{2}{|c|}{ Sigma constant }} & $7.040^{a}$ & $6.197^{a}$ & $4.432^{a}$ & $5.280^{a}$ & $7.040^{a}$ & $6.197^{a}$ & $4.432^{a}$ & $5.280^{a}$ \\
\hline & & $(34.40)$ & $(33.32)$ & $(101.03)$ & $(80.77)$ & $(8.92)$ & $(14.31)$ & $(28.53)$ & $(18.16)$ \\
\hline \multicolumn{2}{|l|}{ \# of maintenance periods } & 19 & 13 & 24 & 56 & 19 & 13 & 24 & 56 \\
\hline \multicolumn{2}{|l|}{ \# of observations } & 14,450 & 9,159 & 28,936 & 52,545 & 14,450 & 9,159 & 28,936 & 52,545 \\
\hline \multicolumn{2}{|l|}{ Pseudo R-squared } & 0.0433 & 0.0566 & 0.0408 & 0.0494 & 0.0433 & 0.0566 & 0.0408 & 0.0494 \\
\hline
\end{tabular}

